\title{
Early intervention with a small molecule inhibitor for tumor necrosis factor-a prevents cognitive deficits in a triple transgenic mouse model of Alzheimer's disease
}

S Prasad Gabbita ${ }^{2}$, Minu K Srivastava², Pirooz Eslami ${ }^{2}$, Ming F Johnson², Naomi K Kobritz ${ }^{2}$, David Tweedie ${ }^{3}$, Nigel H Greig ${ }^{3}$, Frank P Zemlan', Sherven P Sharma ${ }^{2}$ and Marni E Harris-White ${ }^{2^{*}}$

\begin{abstract}
Background: Chronic neuroinflammation is an important component of Alzheimer's disease and could contribute to neuronal dysfunction, injury and loss that lead to disease progression. Multiple clinical studies implicate tumor necrosis factor-a as an inflammatory mediator of neurodegeneration in patients with Alzheimer's because of elevated levels of this cytokine in the cerebrospinal fluid, hippocampus and cortex. Current Alzheimer's disease interventions are symptomatic treatments with limited efficacy that do not address etiology. Thus, a critical need exists for novel treatments directed towards modifying the pathophysiology and progression.

Methods: To investigate the effect of early immune modulation on neuroinflammation and cognitive outcome, we treated triple transgenic Alzheimer's disease mice (harboring PS1 ${ }_{\mathrm{M} 146 \mathrm{~V}}$ APP $_{\mathrm{Swe}}$ and taup301L transgenes) with the small molecule tumor necrosis factor-a inhibitors, 3,6'-dithiothalidomide and thalidomide, beginning at four months of age. At this young age, mice do not exhibit plaque or tau pathology but do show mild intraneuronal amyloid beta protein staining and a robust increase in tumor necrosis factor-a. After 10 weeks of treatment, cognitive performance was assessed using radial arm maze and neuroinflammation was assessed using biochemical, stereological and flow cytometric endpoints.
\end{abstract}

Results: 3,6'-dithiothalidomide reduced tumor necrosis factor-a mRNA and protein levels in the brain and improved working memory performance and the ratio of resting to reactive microglia in the hippocampus of triple transgenic mice.

In comparison to non-transgenic controls, triple transgenic Alzheimer's disease mice had increased total numbers of infiltrating peripheral monomyelocytic/granulocytic leukocytes with enhanced intracytoplasmic tumor necrosis factor-a, which was reduced after treatment with 3,6'-dithiothalidomide.

Conclusions: These results suggest that modulation of tumor necrosis factor-a with small molecule inhibitors is safe and effective with potential for the long-term prevention and treatment of Alzheimer's disease.

Keywords: Alzheimer's disease, memory, neuroinflammation, thalidomide, thiothalidomide, tumor necrosis factor-alpha

\footnotetext{
* Correspondence: marni@ucla.edu

${ }^{2}$ Veterans Administration-Greater Los Angeles Healthcare System and Department of Medicine, David Geffen School of Medicine at UCLA, 11301 Wilshire Boulevard, (151), Los Angeles, CA 90073, USA

Full list of author information is available at the end of the article
} 


\section{Introduction}

Tumor necrosis factor- $\alpha$ (TNF $\alpha)$ is a pleiotropic cytokine originally recognized for its anti-tumor activity [1]. TNF $\alpha$ plays a pivotal role in a wide variety of events mediated by ligation and signaling through one of its cognate receptors, TNF-RI or TNF-RII. In the central nervous system (CNS), TNF $\alpha$ influences both developmental and pathophysiological processes. These include promoting apoptosis during neuronal target innervation [2], altering neurogenesis [3], influencing cell fate determination [4], neuronal differentiation [5] and neuronal morphology [6], augmenting synaptic transmission [7-11] and induction and perpetuation of the innate response during neurodegenerative conditions such as multiple sclerosis, Parkinson's disease and Alzheimer's disease (AD) (reviewed in [12]).

$\mathrm{AD}$ is a progressive neurodegenerative disease characterized by neurotoxic beta amyloid protein $(A \beta)$, neuritic plaques, intraneuronal tau-containing neurofibrillary tangles, synaptic degeneration, neuronal loss, inflammation and diminished cognitive function. Within the $A D$ neuritic plaque, $A \beta$ peptides $\left(A \beta_{1-40}, A \beta_{1-42}\right.$ and so on), derived from amyloid precursor protein (APP), induce inflammation and subsequent neuronal death [13,14]. Sustained, uncontrolled microglial cytokine production drives neuroinflammation-induced AD neurodegeneration [13,15-20]. Supporting this notion, multiple in vitro studies reveal that $A \beta$-stimulated microglia induce synaptic dysfunction and neuron death through an activated cytokine network $[19,21]$. Activated microglia produce several immune and inflammatory mediators (including TNF $\alpha$, IL-1, IL-6) that activate membrane receptormediated intracellular processes in nearby neurons, causing dysfunctional nerve signaling and, ultimately, neuronal death $[19,21]$. Inflammatory mediators also activate nearby microglia, establishing a chronic selfpropagating cycle of glial activation and neuronal death $[15,16,22]$. This self-propagating cycle may underlie the progressive accumulation of synaptic dysfunction and neurodegeneration that leads to the observed cognitive deficits in AD $[13,15,16]$.

Clinical studies highlight the relevance of TNF $\alpha$ in AD. Zhao et al. examined TNF $\alpha$ cascade components in vulnerable neuroanatomic locations of postmortem $\mathrm{AD}$ brains, transitional cases diagnosed with mild cognitive impairment (MCI) and cognitively unimpaired, agematched controls [23]. Cortical and hippocampal TNF $\alpha$ levels were significantly elevated in patients with MCI and with AD compared with age-matched controls. Cerebrospinal fluid (CSF) and serum studies suggest TNF $\alpha$ to be an early biomarker of MCI and AD progression $[24,25]$. TNF $\alpha$ levels in the CSF were 25-fold higher in patients with $\mathrm{AD}$ compared to age-matched controls [24-26] and MCI patients with high CSF TNF $\alpha$ levels progress rapidly to AD [27]. Elevated CSF TNFa levels correlate with clinical deterioration in patients with $\mathrm{MCI}$ and with $\mathrm{AD}$ [26], suggesting that a rise in CSF TNF $\alpha$ level precedes AD development.

Preclinical AD models demonstrate the deleterious role of TNF $\alpha$ in $\mathrm{AD}$-associated pathogenesis and cognitive deficits. Mice receiving $A \beta_{1-40}$ by intracerebroventricular injection show marked deficits in learning and memory concomitant with elevated hippocampal TNF $\alpha$ mRNA levels [28]. In several mouse models that recapitulate specific human AD-related pathologies, TNF $\alpha$ is upregulated, co-localized with amyloid plaques, and is neurotoxic. These include the Tg2576 [29], APPswe/ PS1dE9 [30] and $3 \times$ TgAD mouse models [31].

In the present study, we utilized the $3 \times$ TgAD mouse model, which demonstrates age-dependent changes in entorhinal cortex TNF $\alpha$ mRNA levels that strongly correlate with learning and memory deficits. By 4 months of age, TNF $\alpha$ mRNA levels are elevated 5.3-fold [31] and at this age these mice display early memory retention impairments [32]. Importantly, this TNF $\alpha$ elevation is prior to the onset of overt extracellular amyloid or tau pathology in $3 \times \mathrm{TgAD}$ mice. At 6 months, entorhinal cortex TNF $\alpha$ mRNA levels are 14.8-fold greater and mice demonstrate significant deficits in spatial reference learning. Starting from 4 months of age, $3 \times$ TgAD mice were treated with the small molecule TNF $\alpha$ inhibitor, $3,6^{\prime}$-dithiothalidomide $\left(3,6^{\prime}\right.$-DT), thalidomide (Thal) or vehicle until they were 6.5 months of age. The mice were subsequently tested for cognitive impairment using the eight-arm radial arm maze (RAM) and the brains analyzed by immunohistochemical, biochemical and flow cytometric techniques.

\section{Methods \\ Cell culture: BV2 microglia and splenocytes}

BV2 cells were maintained in culture medium (CM) consisting of Dulbecco's modified Eagle medium (DMEM + LGlutamine, ATCC Cat \#30-2002; Manassas, VA, USA) with 10\% FBS (ATCC Cat \#30-2020), penicillin/streptomycin $(10,000 \mathrm{IU}$ to $10,000 \mu \mathrm{g} / \mathrm{mL}$; ATCC Cat\#30-2300) in a $5 \%$ $\mathrm{CO}_{2}$ incubator. Plated cells (30,000 cells/well; 96-well plate) were grown in CM. In all experiments, cells were treated with the indicated concentrations of 3,6'-DT, Thal or vehicle (dimethyl sulfoxide; DMSO) in the absence or presence of lipopolysaccharide (LPS; $1 \mathrm{ng} / \mathrm{mL}$; serotype O55:B5 from Escherichia coli) in serum-free CM. The final concentration of DMSO was $1 \%$. The media was collected at $24 \mathrm{~h}$ after drug and LPS stimulation, briefly centrifuged to remove floating cells and debris and stored at $-20^{\circ} \mathrm{C}$ prior to ELISA analysis. Lactate dehydrogenase (LDH) assay (Promega CytoTox96 non-radioactive cytoxicity assay; Madison, WI, USA) was performed in triplicate on CM as per manufacturer's protocol. 
For analyses of spleen TNF $\alpha$ production, spleens from Non- $\mathrm{Tg}$ and $3 \times \mathrm{Tg}$ mice were mechanically dissociated on a wire mesh by crushing with a $10 \mathrm{~mL}$ syringe, the red blood cells depleted, and filtered through $70 \mu \mathrm{m}$ nylon strainers (BD Biosciences, San Diego, CA, USA). Splenocytes $\left(2.5 \times 10^{6}\right.$ cells $\left./ \mathrm{mL}\right)$ were cultured in CM in triplicate for $24 \mathrm{~h}$ and TNF $\alpha$ secreted in the CM quantified by ELISA.

\section{Animal studies}

C57/Bl6 male mice were used for LPS injection studies (same LPS serotype as used in the in vitro studies). In this study, homozygous $3 \times \mathrm{TgAD}$ mice expressing mutant human genes APPswe, PS1M146V and tauP301L (previously characterized by Oddo et al. [33]) and wildtype mice from the same hybrid background strain, 129/ C57BL6, were used. Starting from 4 months of age, $3 \times \operatorname{TgAD}$ mice received a daily intraperitoneal (i.p.) in-

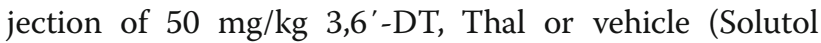
(Sigma-Aldrich, St. Louis, MO,USA) in saline). Mice were housed on a $12 \mathrm{~h}$ light and $12 \mathrm{~h}$ dark schedule. All mice were given access to food and water ad libitum. At 6 months of age, the cognitive ability of the mice was assessed. All procedures involving animals were approved by the Institutional Animal Care and Use Committee at the Veterans Administration-Greater Los Angeles Healthcare System.

\section{Radial arm maze}

The RAM used in this study consists of eight equally spaced arms radiating from a small circular central platform. The arms were $35.0 \mathrm{~cm}$ in length, $5.0 \mathrm{~cm}$ in width and $9 \mathrm{~cm}$ high (ANY-maze; Stoelting Co., Wood Dale, IL, USA; Item 60150). The maze was elevated $94 \mathrm{~cm}$ above the floor with each arm and the central platform supported underneath by a small wood table. Extramaze cues that surrounded the maze included the experimenter, two stainless steel racks, one wall-mounted storage cabinet and a sink. The cues were kept in consistent positions throughout the experiment and the maze was uniformly lit from ceiling lighting.

\section{Behavioral procedure}

After mice were food-deprived to $90 \%$ of their ad libitum body weight, behavioral training began. For the first phase of behavioral training, mice were habituated to the maze for seven consecutive days. During habituation, three sucrose pellets (10 mg; P. J. Noyes Company, Inc., Lancaster, NH, USA) were placed down each of the eight arms of the RAM. Mice were released to the center platform and allowed to explore all eight arms, and arm visits as well as sucrose pellet consumption were recorded. Mice remained on the maze for 5 min during each daily habituation trial. Mice that did not consume any sucrose pellets or freely explore the maze by the end of the habituation period were excluded from behavioral testing.

After habituation was complete, the second phase of behavioral training began. Four arms were randomly selected for each animal and baited at the far end of each arm. Mice were released from the center platform, and arm visits were recorded. The training trial was considered complete when all four pellets were consumed or $5 \mathrm{~min}$ had passed. Two types of errors were recorded; working memory errors were revisits to arms that had been previously baited on the same training trial, and reference memory errors were visits to any of the four arms that had never been baited. In this phase of training, mice were trained for 9 consecutive days. The maze was wiped clean after each training trial using paper towels that were dampened with water.

\section{Tissue collection}

Twenty-four hours after the last 3,6'-DT, Thal or vehicle injection, animals were anesthetized with pentobarbital and cardiac perfused with HEPES buffer (10 mM HEPES, $137 \mathrm{mM}$ sodium chloride, $4.6 \mathrm{mM}$ potassium chloride, $1.1 \mathrm{mM}$ potassium phosphate monobasic, $0.6 \mathrm{mM}$ magnesium sulfate and $1.1 \mathrm{mM}$ ethylenediaminetetraacetic acid) containing sodium vanadate $(1 \mathrm{mM})$, sodium pyrophosphate $(1 \mathrm{mM})$, sodium fluoride $(50 \mathrm{mM})$, leupeptin $(0.002 \mathrm{mM})$, aprotinin $(0.154 \mu \mathrm{M})$, pepstatin $(1.46 \mu \mathrm{M})$ and phenylmethylsulfonyl fluoride $(287.36 \mu \mathrm{M})$. The hippocampus and cortex were dissected from one hemisphere and either snap-frozen in liquid nitrogen (half cortex) and stored in a $-80^{\circ} \mathrm{C}$ freezer or stored at $-20^{\circ} \mathrm{C}$ in RNAlater (Ambion Inc., Austin, TX, USA) for PCR analysis. The contralateral hemisphere was immersion fixed in formalin (Fisher Scientific, Pittsburgh, PA, USA) for $24 \mathrm{~h}$ followed by paraffin embedding.

\section{Enzyme-linked immunosorbent assay}

The levels of TNF $\alpha$ in culture media or mouse cortical or spleen supernatants were measured using a commercially available ELISA kit for mouse TNF $\alpha$ (BioLegend ELISA MAX; BioLegend, San Diego, CA, USA) according to manufacturer's instructions. This kit detects optimally in the 10 to $1,000 \mathrm{pg} / \mathrm{mL}$ range. Standards ranged from $7.8 \mathrm{pg} / \mathrm{mL}$ to $500 \mathrm{pg} / \mathrm{mL}$ in all assays. Samples were appropriately diluted to fall within the standard range and not below.

In brief, $250 \mu \mathrm{L}$ of tissue extraction reagent (Invitrogen, Camarillo, CA, USA; Cat \# FNN0071), containing protease inhibitor cocktail (Sigma-Aldrich; Cat \# P2714), was added to each tissue sample. Tissue was homogenized with 20 passes of a Teflon pestle homogenizer. Homogenates were centrifuged at $10,000 \mathrm{rpm}$ for $10 \mathrm{~min}$ at $4^{\circ} \mathrm{C}$ and the resulting supernatants were removed and stored at $-20^{\circ} \mathrm{C}$ until use. 


\section{Real time quantitative PCR analysis of tumor necrosis factor-a gene expression}

The samples were stored in RNAlater (Ambion Inc.) at $-20^{\circ} \mathrm{C}$. Total RNA was extracted using TRI reagent (Sigma-Aldrich) and BCP (Molecular Research Center, Inc., Cincinnati, OH, USA) as a phase separation reagent. RNA was purified using Qiagen's RNeasy Kit (Qiagen, Germantown, MD, USA) and was quantified spectrophotometrically. RNA $(1 \mu \mathrm{g})$ was reverse transcribed to cDNA using $\mathrm{RT}^{2}$ First Strand Kit (Qiagen). Real time quantitative (q)PCR, using an ABI 7300 Sequence Detection System (Applied Biosystems, Foster City, CA, USA), was performed for quantification of low-density TNF $\alpha$ mRNA. The amounts of mouse TNF $\alpha$ mRNA were determined by amplification of the cDNA target using the $\mathrm{RT}^{2}$ qPCR Primer Assay for TNF $\alpha$ (Qiagen). To normalize the quantification of TNF $\alpha$ mRNA for possible differences in the amount of each cDNA template, $18 \mathrm{~S}$ rRNA served as a housekeeping gene. PCR amplifications of TNF $\alpha$ and $18 \mathrm{~S}$ rRNA genes were carried out in conjunction with $\mathrm{RT}^{2}$ qPCR SYBR Green Master Mix (Qiagen). Each cDNA sample was tested in triplicate. The following temperature parameters were cycled 40 times: $15 \mathrm{~s}$ at $95^{\circ} \mathrm{C}, 1 \mathrm{~min}$ at $60^{\circ} \mathrm{C}$. Standard curves were constructed for $18 \mathrm{~S}$ rRNA as an internal standard and for the TNF $\alpha$ gene. The amounts of TNF $\alpha$ mRNA gene expression was normalized by division by the amount of $18 \mathrm{~S}$ rRNA mRNA in each sample and expressed as fold change in comparison to control values.

\section{Immunohistochemistry, thioflavin S and stereology}

Formalin-fixed brains were embedded in paraffin and $35 \mu \mathrm{m}$ thick coronal sections were mounted on glass slides. Immunohistochemical staining for anti-ionized calcium-binding adapter molecule 1 to identify microglia (Iba-1, 1:800; Wako Chemicals, Neuss, Germany) or monoclonal biotinylated 6E10 primary antibody (1:1000; Covance, San Diego, CA, USA) for total APP/A $\beta$ was performed on these sections with the VectaStain Elite $\mathrm{ABC}$ kit (Vector Laboratories, Burlingame, CA, USA). Diaminobenzadine (Sigma-Aldrich) was used as the chromagen. For $6 \mathrm{E} 10$, antigen retrieval using $70 \%$ formic acid for 3 min was performed prior to antibody staining.

Design-based stereology was used to quantify Iba-1 and 6E10 positive cells in the hippocampus. We used the optical fractionator method, a stereological method of unbiased cell counting within a defined volume, using Microbrightfield (MBF) Bioscience's Stereo Investigator software (Williston, VT, USA).. The optical fractionator technique estimates the number of cells by multiplying the sum of cells counted by the reciprocal of the fraction of the region sampled. Briefly, sections were viewed with a Nikon E600 microscope with a motorized stage, interfaced with a computer running Stereo Investigator 9.0.
The total hippocampus (Iba-1) and CA1 to CA2 region (6E10) were identified on slide-mounted sections and delineated for each section of each animal under a $2 x$ objective, based on the atlas of Franklin and Paxinos [34]. Tissue thickness was measured at each sampling site with a standard guard zone of $2 \mu \mathrm{m}$ applied throughout. Every fifth section was analyzed for a total of eight sections per mouse, beginning at bregma $-1.455 \mathrm{~mm}$ and ending at $-2.680 \mathrm{~mm}$ for Iba-1, and from bregma $-1.525 \mathrm{~mm}$ to $-2.750 \mathrm{~mm}$ for $6 \mathrm{E} 10$. All sampling was done under a $60 \times$ oil immersion objective. In addition to $6 \mathrm{E} 10+$ cell counts, $6 \mathrm{E} 10$ staining density in the CA1 to CA2 region of the hippocampus was evaluated using Image Pro Plus 5.0.1.11(Bethesda, MD, USA).

For thioflavin $\mathrm{S}$, three sections (every fifth section beginning at bregma $-1.490 \mathrm{~mm}$ and ending at $-1.840 \mathrm{~mm}$ ) were incubated for $8 \mathrm{~min}$ in an aqueous solution of thioflavin $\mathrm{S}$ $(1 \% \mathrm{w} / \mathrm{v})$ and then differentiated twice with $80 \%$ ethanol for 3 min each, followed by another 3 min wash with $95 \%$ ethanol. Sections were rinsed three times with double distilled water and coverslipped with Vectashield fluorescence mounting medium (Vector Laboratories).

\section{Flow cytometry}

Flow cytometry was performed on a single cell suspension of brain-infiltrating leukocytes that were isolated using a protocol based on the separation of microglia and leukocytes by density centrifugation, as previously described [35]. Briefly, following perfusion with ice- cold $1 \times$ Hank's Balanced Salt Solution without phenol red to remove blood, the brain (without cerebellum) was homogenized in Roswell Park Memorial Institute medium using a dounce homogenizer with loose (pestle A) and tight-fitting (pestle B) pestles and the cell suspension layered over a discontinuous Percoll gradient. The cell layer at the $70 \%$ to $30 \%$ Percoll interface was transferred to a clean conical tube, diluted three times with $1 \times$ Hank's Balanced Salt Solutionand centrifuged to pellet the cells. The pellet was re-suspended in $1 \mathrm{~mL}$ of cell staining buffer in preparation for cell counting and flow cytometry.

The fluorescent-conjugated flow anti-mouse Abs allophycocyanin (APC)-conjugated anti-GR1 (RB6-8 C5) was from BioLegend. Peridinin-chlorophyll-protein-complex (PerCP)-conjugated anti-mouse CD45 (30-F11) was from BD Biosciences. APC-Cy7conjugated anti-mouse LY6G (1A8) and phycoerythrin (PE) -conjugated anti-mouse TNF $\alpha$ (MP6-XT22) were purchased from eBiosciences (San Diego, CA, USA). For flow cytometric evaluation, leukocytic cell populations (approximately $10^{6}$ ) were stained in a volume of $50 \mu \mathrm{L}$ of $2 \% \mathrm{FBS} / \mathrm{PBS}$ containing a cocktail of three cell surface antibodies (anti-CD45, antiGr1 and anti-LY6G) for $30 \mathrm{~min}$ on ice and then stained for intracytoplasmic TNF $\alpha$ expression using BD Biosciences 
cytofix/cytoperm solution, according to the manufacturer's instructions. The stained cell samples were acquired on a FACSScan or FACSCalibur flow cytometer (Becton Dickinson, San Jose, CA, USA) in the University of California, Los Angeles, Jonsson Cancer Center Flow Cytometry Core Facility. A total of 10,000 to 25,000 gated events were analyzed using FCS Express 3 (De Novo Software, Thornhill, ON, Canada). Cells stained with irrelevant isotypematched antibodies and unstained cells served as controls. The cutoffs were set according to control staining.

\section{Statistical analysis}

All data were normally distributed and are presented as mean values \pm standard error of the mean. In the case of single mean comparisons, data were analyzed by unpaired Student's $t$-test. In the case of multiple mean comparisons, the data were analyzed by one- or two-way analysis of variance (ANOVA) followed by Bonferroni multiple comparison tests using statistics software (Prism 5.0; GraphPad, LaJolla, CA, USA). P-values less than 0.05 were regarded to reflect a significant difference.

\section{Results}

Thalidomide and 3,6'-dithiothalidomide inhibit tumor necrosis factor-a production induced by lipopolysaccharide both in BV2 microglia cells in vitro and brain cortical tissue in vivo

Initial studies were conducted in vitro to verify the efficacy of Thal and 3,6'-DT (see Figure 1 for chemical structures) to inhibit TNF $\alpha$. BV2 microglial cell cultures were treated with $1 \mathrm{ng} / \mathrm{mL}$ LPS with or without Thal or 3,6' -DT ( 1 and $10 \mu \mathrm{M})$. Culture media ( $\mathrm{n}=6$ wells/treatment) was collected $24 \mathrm{~h}$ later and evaluated for TNF $\alpha$ protein levels via ELISA (Figure 2) and cytotoxicity by measuring $\mathrm{LDH}$ release into the media. One-way ANOVA revealed a significant effect of treatment $\left(\mathrm{F}_{7,23}=51.03 ; P<0.0001\right)$. Both Thal and 3,6' ${ }^{\prime} \mathrm{DT}$ significantly inhibited BV2 TNF $\alpha$ production at both concentrations compared with LPS alone $(P<0.0001$ versus both drugs, both doses). 3,6'-DT was a more potent inhibitor, with a half maximal inhibitory concentration $\left(\mathrm{IC}_{50}\right)$ value for TNF $\alpha$ inhibition of approximately $1 \mu \mathrm{M}$

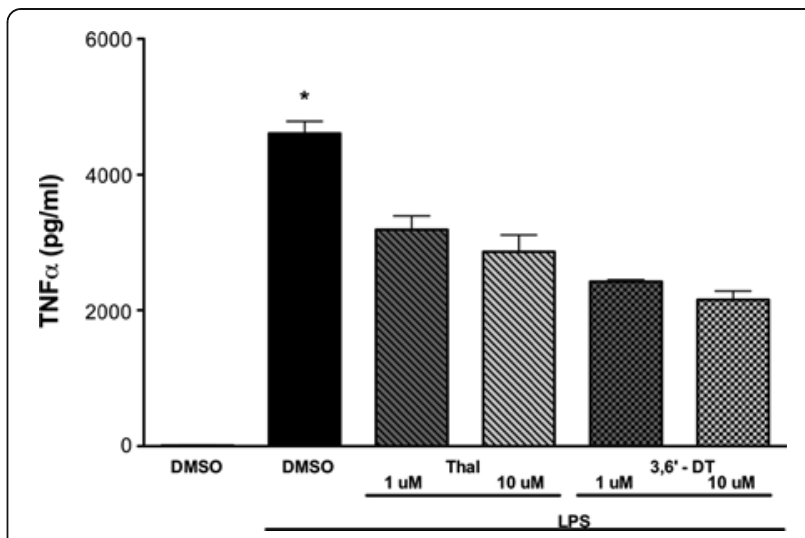

Figure 2 Thalidomide and 3,6'-dithiothalidomide attenuate lipopolysaccharide-induced increase in tumor necrosis factor-a. BV2 cells were treated with $1 \mathrm{ng} / \mathrm{mL}$ LPS \pm Thal or 3,6'-DT for $24 \mathrm{~h}$. Initial studies in BV2 cells demonstrate that both Thal and 3,6'-DT are effective at attenuating LPS-induced TNFa release into culture media. 3,6'-DT has an $I C_{50}$ value of approximately $1 \mu \mathrm{M}$ whereas the $\mathrm{IC}_{50}$ for Thal is $>10 \mu \mathrm{M} . \mathrm{n}=6$ per group. One-way analysis of variance: $P<0.0001$; ${ }^{*} P<0.001$ versus both drugs, both doses. LPS:

lipopolysaccharide; Thal: thalidomide; TNFa: tumor necrosis factor-a; 3,6'-DT: 3,6'-dithiothalidomide.

while the $\mathrm{IC}_{50}$ value of Thal was in excess of $10 \mu \mathrm{M}$, which is congruent with previous publications [36]. There was no increase in $\mathrm{LDH}$ in any treatment group including DMSO alone, LPS alone, Thal or 3,6'-DT alone or LPS plus Thal or 3,6'-DT (data not shown).

Both Thal and 3,6'-DT were effective at inhibiting brain cortical TNF $\alpha$ mRNA and protein levels in a systemic in vivo model of inflammation using LPS (Figure 3). C57 mice were given an i.p. injection of $100 \mathrm{mg} /$ $\mathrm{kg}$ Thal or 3,6'-DT 30 minutes prior to an i.p. $5 \mathrm{mg} / \mathrm{kg}$ LPS injection. Four hours later, cortical tissue was harvested and analyzed by RT-PCR and ELISA. One-way ANOVA showed a significant effect of treatment on TNF $\alpha$ gene $\left(\mathrm{F}_{4,29}=39.85 ; P<0.0001\right)$ and protein $\left(\mathrm{F}_{4,29}=34.58 ; P<0.0001\right)$ expression. Both Thal and $3,6^{\prime}$-DT reduced LPS-induced brain cortical TNF $\alpha$ mRNA and protein levels to near vehicle-treated control values $(P<0.0001)$.

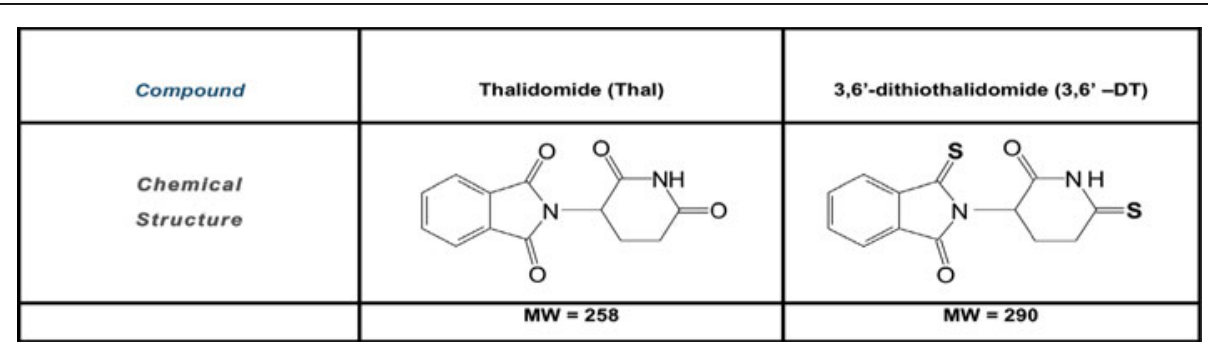

Figure 1 The structures of thalidomide and 3,6'-dithiothalidomide. 

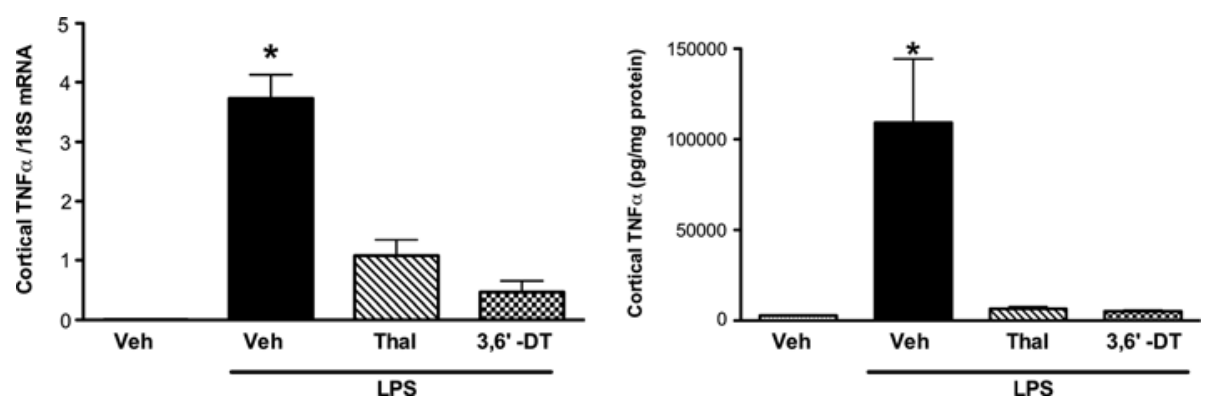

Figure 3 3,6'-dithiothalidomide and thalidomide inhibited lipopolysaccharide-stimulated tumor necrosis factor-a gene and protein expression in C57 mice. Mice were treated peripherally (intraperitoneal injection) with a single equivalent dose (100 mg/kg) of 3,6'-DT or Thal $30 \mathrm{~min}$ prior to a peripheral $5 \mathrm{mg} / \mathrm{kg}$ dose of LPS (intraperitoneal injection). Cortical tissue was harvested 4 hours after LPS injection. $\mathrm{n}=6 \mathrm{per}$ group. One-way analysis of variance: $P<0.001$; ${ }^{*}<0.001$ versus all other groups. LPS: lipopolysaccharide; Thal: thalidomide; TNFa: tumor necrosis factor-a; 3,6'-DT: 3,6'-dithiothalidomide.

\section{3,6'-dithiothalidomide, but not thalidomide, prevents cognitive impairment}

Beginning at 4 month of age, $3 \times \mathrm{Tg}$ mice were treated with Thal, 3,6'-DT or vehicle for 2.5 months. There were no observable adverse effects of daily i.p. administration of Thal or 3,6'-DT. Mice were habituated to the RAM and were fully ambulatory and explored the RAM normally. Both working and reference memory errors were quantified during all acquisition sessions. Figure 4A,B represents the effect of treatment on working memory errors and reference memory errors made during the acquisition test, respectively. Repeated measures ANOVA showed a statistical effect of treatment on working memory errors $\left(F_{3}, 432=2.92\right.$, $P=0.042$, Figure $4 \mathrm{~A})$ and a significant interaction of 'treatment by sessions' $\left(\mathrm{F}_{24}, 432=2.38, P=0.0003\right.$, Figure $\left.4 \mathrm{~A}\right)$. On day $9,3 \times \mathrm{Tg}$ (vehicle) mice performed significantly worse than Non-Tg mice (* $P<0.05$, Bonferroni post hoc analysis), and $3 \times \mathrm{Tg}\left(3,6^{\prime}-\mathrm{DT}\right)$ mice performed significantly better than $3 \times \mathrm{Tg}$ (vehicle) mice $\left({ }^{*} P<0.05\right)$, indicating that spatial learning was impaired in vehicle-treated, but not impaired in 3,6'-DT-treated $3 \times$ Tg mice. A similar statistical analysis revealed that reference memory errors decreased with time $\left(\mathrm{F}_{8}, 432=0.53, P=0.6668\right.$, Figure $\left.4 \mathrm{~B}\right)$ but treatment did not have a significant effect $\left(\mathrm{F}_{3}, \quad 432=260.4, \quad P=0.6488\right.$, Figure $4 B$ ). Figure $4 \mathrm{C}$ indicates that there was no significant difference in time to complete the RAM on day 9 $\left(\mathrm{F}_{3,47}=0.1635 ; P=0.1635\right)$.

\section{3,6'-dithiothalidomide treatment reduces brain and spleen} tumor necrosis factor-a levels

A significant reduction in brain TNF $\alpha$ gene expression was observed in $3 \times \mathrm{Tg}$ mice treated with $3,6^{\prime}$-DT but not with Thal (Figure 5A; $P=0.033$ ). There was a significant effect of treatment on TNF $\alpha$ protein in the cortex (ANOVA $F_{3,35}=4.956 ; P=0.0062$ ) with TNF $\alpha$ protein significantly decreased to near Non-Tg levels by $3,6^{\prime}$-DT $\left(P<0.053 \times \mathrm{Tg}\right.$ (vehicle) versus $\left.3 \times \mathrm{Tg}\left(3,6^{\prime}-\mathrm{DT}\right)\right)$ but not by Thal treatment (Figure $5 \mathrm{~B}$ ). In contrast, both Thal and 3,6'-DT were effective at reducing TNF $\alpha$ protein in the periphery as assessed by 24-h splenocyte production of TNF $\alpha$ (Figure 6). One-way ANOVA for treatment was significant $(\mathrm{F} 3,13=5.374 ; P=0.0184)$ with $P<0.05$ for $3 \times \mathrm{Tg}$ (vehicle) versus $3 \times \mathrm{Tg}\left(3,6^{\prime}-\mathrm{DT}\right)$. The reduction was not significant for $3 \times \mathrm{Tg}$ (vehicle) versus $3 \times \mathrm{Tg}$ (Thal).

\section{3,6'-dithiothalidomide improves the ratio of resting to activated microglia}

Using unbiased stereological methods, we examined changes in Iba- 1 positive microglia in the hippocampus of $3 \times \mathrm{Tg}$ (vehicle, thalidomide- and 3,6'-DT-treated) and Non-Tg mice ( $\mathrm{n}=3$ to 4 per group) and found a significant effect of treatment on total $\left(F_{3,8}=5.565\right.$; $P<0.0233)$, activated $\left(\mathrm{F}_{3,8}=20.88 ; P=0.0004\right)$ and resting $\left(\mathrm{F}_{3,8}=17.17 ; P=0.0008\right)$ microglia (Figure 7$)$. Treatment of $3 \times \mathrm{Tg}$ mice with $3,6^{\prime}$-DT or Thal was effective at reducing the total number of Iba-1 positive brain microglia (Figure 7 Cc-Dd). Only 3,6' -DT increased the ratio of resting microglia to activated microglia (as assessed morphologically; see Figure 7, upper panel) resulting in a microglial morphological profile in the hippocampus that is more similar to the Non-Tg hippocampus.

\section{Amyloid precursor protein/amyloid beta peptide staining is not changed by treatment with thalidomide or 3,6'- dithiothalidomide}

The number of $6 \mathrm{E} 10+$ cells in the CA1 to CA2 region of the hippocampus was not changed by either Thal or 3,6'-DT treatment. Intraneuronal $6 \mathrm{E} 10$ staining was light at 6.5 months of age in the $3 \times \mathrm{Tg}$ mice with only an occasional diffuse plaque found and the majority of the staining was confined to cells in the hippocampus and cortex. Figure 8 shows representative sections of the CA1 to CA2 region of 

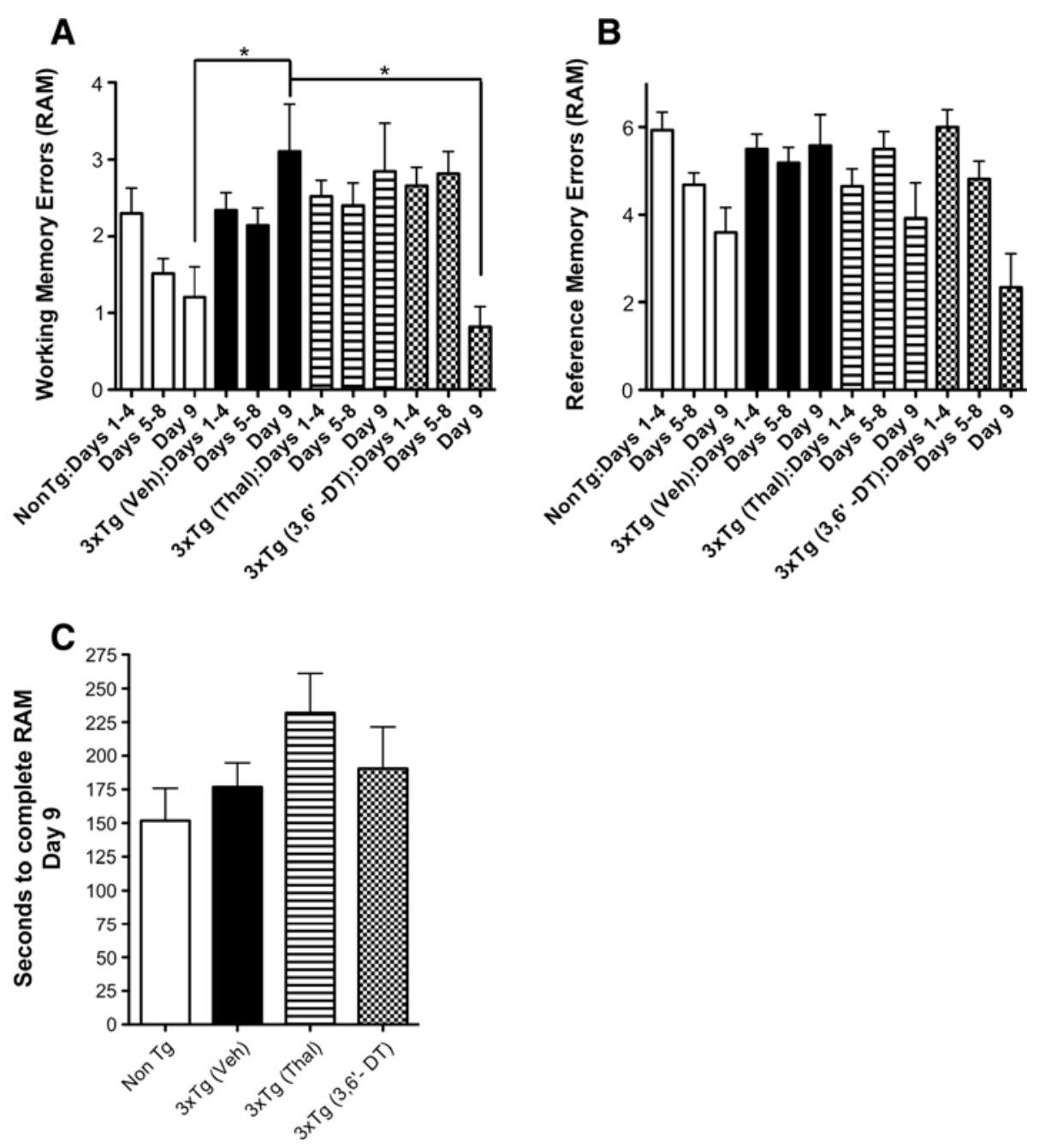

Figure 4 3,6'-dithiothalidomide improves cognitive performance as assessed using the eight-arm radial arm maze in $3 \times \mathrm{Tg}$ mice. (A) 6.5-month-old $3 \times \mathrm{Tg}$ mice demonstrate a significant working memory deficit relative to age-matched Non-Tg mice $(n=15)$. Daily intraperitoneal administration of $50 \mathrm{mg} / \mathrm{kg}, 3,6^{\prime}$-DT for 2.5 months (4 to 6.5 months of age) significantly improved working memory errors (WME) in $3 \times T g$ mice $(n=11)$ compared with vehicle-treated $(n=14)$ or Thal-treated $(50 \mathrm{mg} / \mathrm{kg}$ intraperitoneal injection; $n=11) 3 \times \operatorname{Tg}$ mice. No difference in WME was observed between 3, 6'-DT-treated $3 \times$ Tg mice and age-matched Non-Tg mice. One-way analysis of variance: $P=0.0076 .{ }^{*} P<0.05$. (B) Reference memory errors and $\mathbf{( C )}$ time to complete the radial arm maze on the last day of testing were not significantly different between groups. Thal: thalidomide; TNFa: tumor necrosis factor-a; 3,6'-DT: 3,6'-dithiothalidomide; WME: working memory errors.

the hippocampus. Stereological counts of CA1 to CA2 did not reveal differences across treatment groups in either numbers of $6 \mathrm{E} 10+$ cells in this region or in $6 \mathrm{E} 10$ optical density. At 6.5 months of age, thioflavin $\mathrm{S}+$ deposits were not seen in the $3 \times \mathrm{Tg}$ mouse model [37] and none were observed in 6.5 month control $3 \times \mathrm{Tg}$ mice in this study. Treatment with Thal or 3,6' -DT did not alter this.

\section{3,6'-dithiothalidomide reduces tumor necrosis factor- $\alpha$ in central nervous system-infiltrating leukocytes}

Infiltrating leukocytes were isolated from whole brains to determine if treatment could alter the numbers of peripherally infiltrating cells (Figure 9; ANOVA F3,11 = 85.19; $P$
$<0.0001) .3 \times \mathrm{Tg}$ mice have greater than twice the numbers of infiltrating leukocytes as Non-Tg mice $(P<0.001)$. These infiltrates were derived from whole brain homogenates and it is unknown to what extent these leukocytes migrated into the brain parenchyma or if they were maintained in the perivascular compartments of the brain. Both Thal and 3,6'-DT reduced the numbers of these cells $(P<0.0001$ versus $3 \times \mathrm{Tg}$ (vehicle) $)$. 3,6'-DT was more effective than Thal at reducing the numbers of infiltrating leukocytes $\left(P<0.001 ; 3 \times \mathrm{Tg}\left(3,6^{\prime}\right.\right.$-DT $)$ versus $3 \times \mathrm{Tg}(\mathrm{Thal}))$, reducing the numbers well below NonTg cell numbers $\left(P<0.001 ; 3 \times \mathrm{Tg}\left(3,6^{\prime}-\mathrm{DT}\right)\right.$ versus Non$\mathrm{Tg})$. 

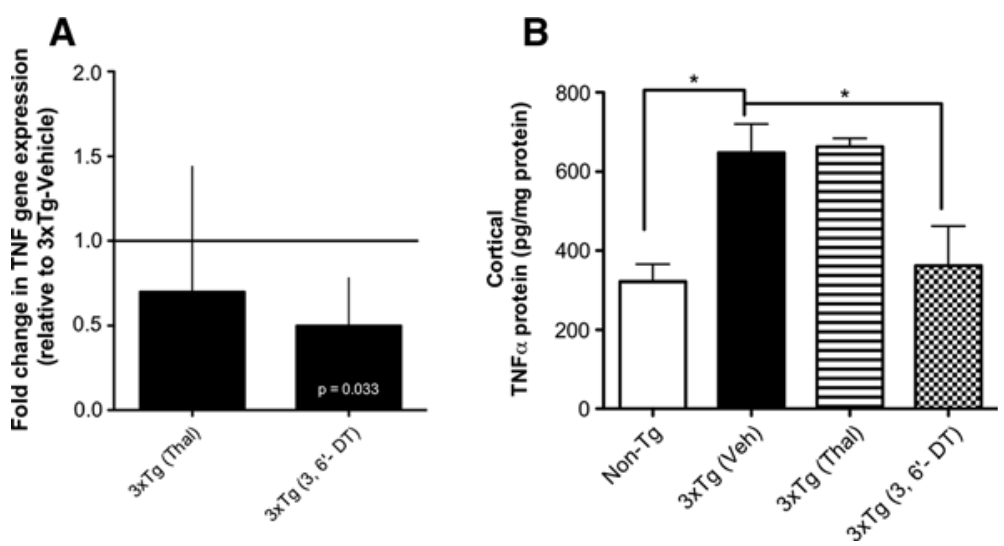

Figure 5 Tumor necrosis factor-a gene and protein expression in the $\mathbf{3} \times \mathbf{T g}$ mouse. (A) Fold-change $(2 \wedge(-\delta \delta C t))$ is the normalized gene expression $(2 \wedge(-\delta C t))$ in the test sample $(3 \times \operatorname{Tg}$ treated with Thal or 3,6'-DT) divided by the normalized gene expression $(2 \wedge(-\delta C t))$ in the control sample (vehicle-treated $3 \times \mathrm{Tg}$ ). Fold-change values of less than one indicate a negative- or downregulation. Both Thal and 3,6'-DT downregulated TNFa gene expression but the value was significant only in the 3,6'-DT group $(P=0.033)$. (B) TNFa protein levels are doubled in the cortex of $3 \times \mathrm{Tg}$ mice compared with Non-Tg mice. 3,6'-DT, but not Thal, reduced TNFa protein levels near to Non-Tg levels in $3 \times \mathrm{Tg}$ mice. $n=5$ to 8 per group. One-way analysis of variance $\left(P=0.062,{ }^{*} P<0.05\right)$. Thal: thalidomide; TNFa: tumor necrosis factor-a; 3,6'-DT: 3,6'-dithiothalidomide.

\section{3,6'-dithiothalidomide decreased tumor necrosis factor-a} in myelomonocytic/granulocytic cells

CNS-infiltrating leukocytes were isolated and stained for fluorescence activated cell sorting (FACS) analysis to

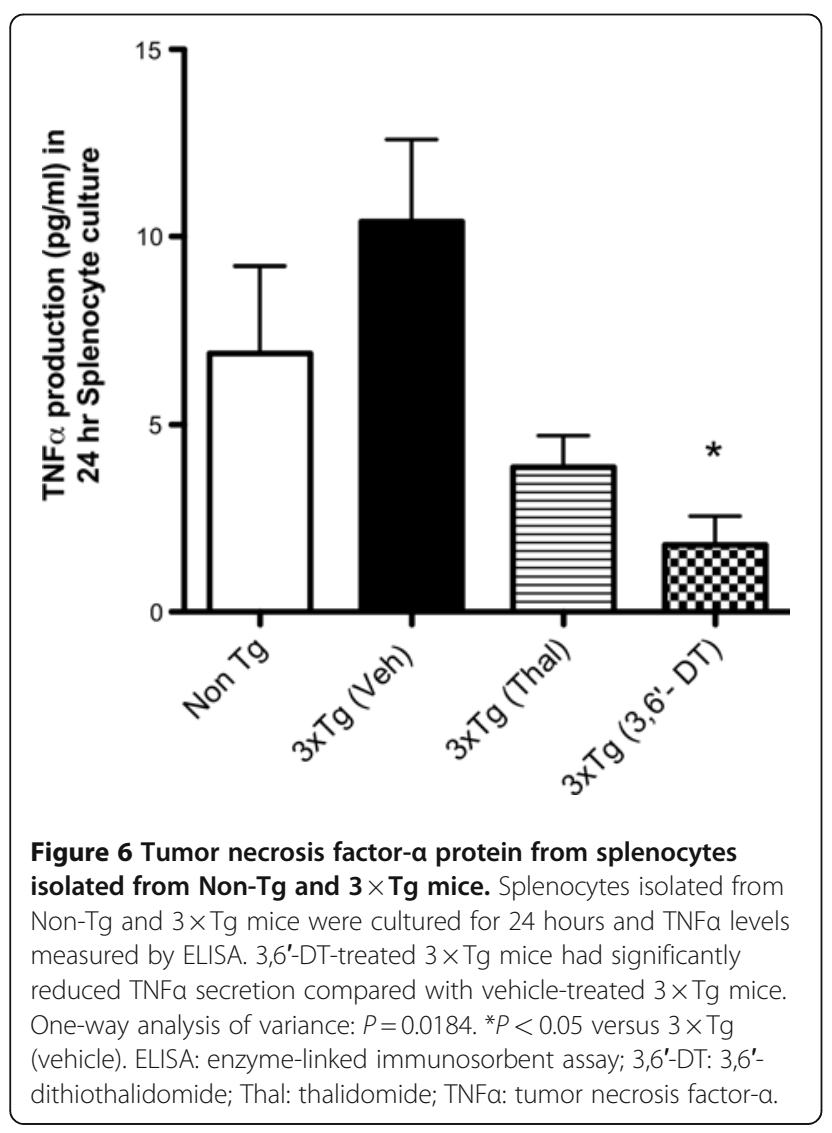

evaluate the changes in the CD45 hi population and their TNF $\alpha$ expression (Figure 10 and Table 1). There was a trend towards increased percentage of CD45 $5_{\text {hi }}$ (ANOVA; $P=0.16$ ) and $\mathrm{CD} 45_{\mathrm{hi}} / \mathrm{Gr} 1^{+} / \mathrm{Ly}_{6 \mathrm{G}}$ (myelomonocytic/granulocytic; ANOVA $P=0.10$ ) populations in the $3 \times$ Tg relative to Non-Tg mice. TNF $\alpha$ production was increased in both the CD $45_{\mathrm{hi}}$ and the $\mathrm{CD} 45_{\mathrm{hi}} / \mathrm{Gr} 1^{+} / \mathrm{Ly}_{6 \mathrm{Gi}}$ populations in the $3 \times \mathrm{Tg}$ mice relative to Non-Tg mice. 3,6'-DT reduced TNF $\alpha$ levels in the $\mathrm{CD} 45_{\mathrm{hi}} / \mathrm{Gr} 1^{+} / \mathrm{Ly}_{6 \mathrm{G}}$ population $(P=0.0309)$.

\section{Discussion}

There is a robust increase in TNF $\alpha$ expression levels in the CNS during numerous experimental models of both acute injury and chronic neurodegenerative disease, such as $\mathrm{AD}$, suggesting a significant role for this cytokine in the injury or disease process $[12,38]$. Neuroinflammation begins early in $\mathrm{AD}$ and accompanies $\mathrm{A} \beta$ accumulation and neurodegeneration [39]. Still nebulous is whether this AD-related inflammatory response is advantageous or deleterious and what the best approach is to resolving the inflammatory tide while simultaneously allowing beneficial processes to continue. In the current study, we focus on the central role of TNF $\alpha$ and its modulation in inflammatory regulation and cognitive function in the $3 \times \mathrm{Tg}$ mouse model of AD.

Although there is ample evidence that TNF $\alpha$ plays a central role in brain development and homeostatic and repair mechanisms [40], many studies demonstrate a negative role for TNF $\alpha$ in AD pathology. APP/presenilin 1 (PS1) transgenic mice receiving short-term CNS infusion of anti-TNF $\alpha$ monoclonal antibody showed reduced 

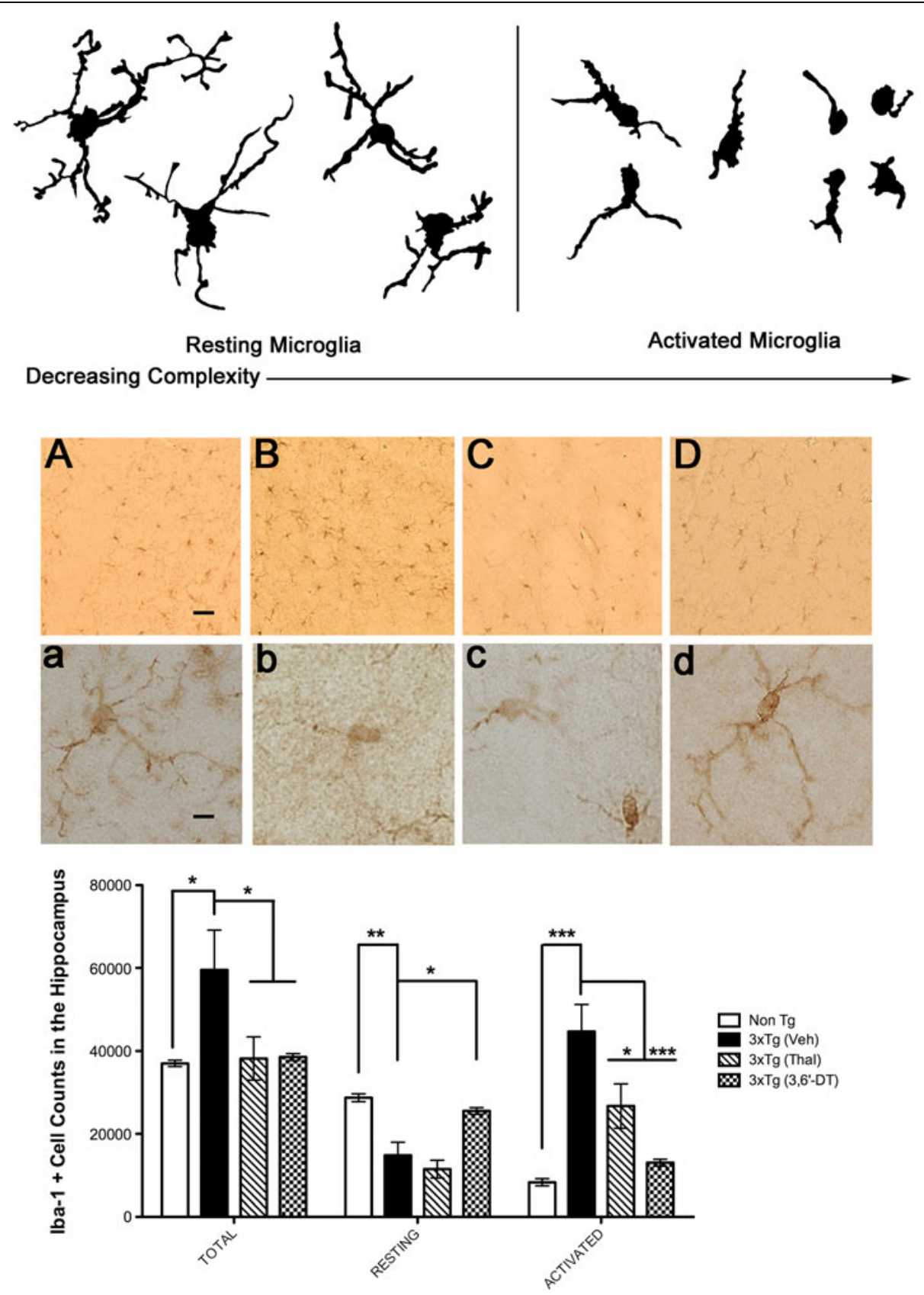

Figure 7 Stereological analysis of ionized calcium-binding adapter molecule 1 staining in the hippocampus. Unbiased stereological methods were used to analyze $35 \mu \mathrm{m}$ sections, every fifth section through the hippocampus (total of eight sections per mouse; $n=3$ to 4 per group). The top panel shows the morphological criteria used for designating resting versus activated lba-1 positive microglia. Middle Panel: (Aa) Non-Tg; (Bb) $3 \times \mathrm{Tg}$ (vehicle); (Cc) $3 \times \mathrm{Tg}$ (Thal); (Dd) $3 \times \operatorname{Tg}$ (3,6'-DT) mice. Bottom panel: total, resting and activated cell counts. Bonferroni post hoc testing: ${ }^{*} P<0.05$, ${ }^{* *} P<0.01$, ${ }^{* *} P<0.001$. Bar equals $40 \mu \mathrm{m}$ (A), $10 \mu \mathrm{m}$ (a). 3,6'-DT: 3,6'-dithiothalidomide; Iba-1: ionized calcium-binding adapter molecule 1; Thal: thalidomide.

tau pathology and amyloid plaque deposits [41]. Ligation of microglial CD40 with its cognate ligand, CD40 ligand (CD40L, expressed by activated astrocytes associated with beta-amyloid plaques [42]), synergistically activated microglia to produce TNFa in response to low levels of
A $\beta$ peptides. This form of microglial activation was deleterious, as it resulted in TNF $\alpha$-dependent neuronal injury. Further, when mice deficient in CD40L were crossed with the $\operatorname{Tg} 2576$ mouse model of AD, abnormal phosphorylation of tau (an index of neuronal stress) was 

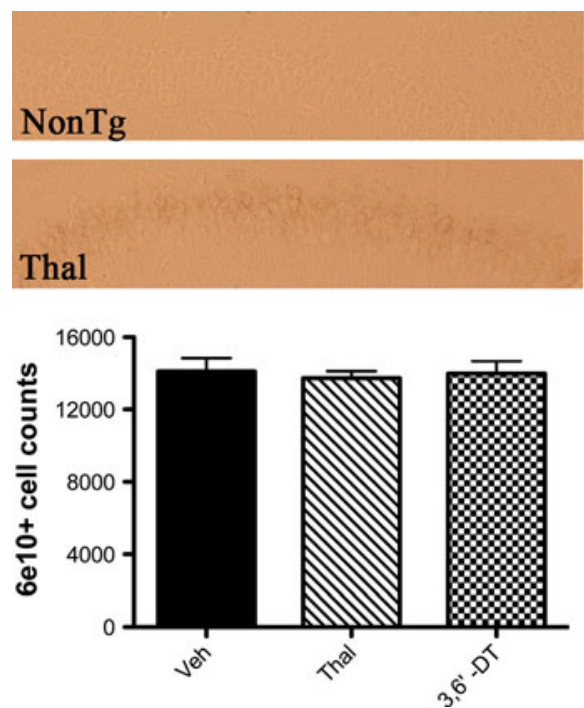
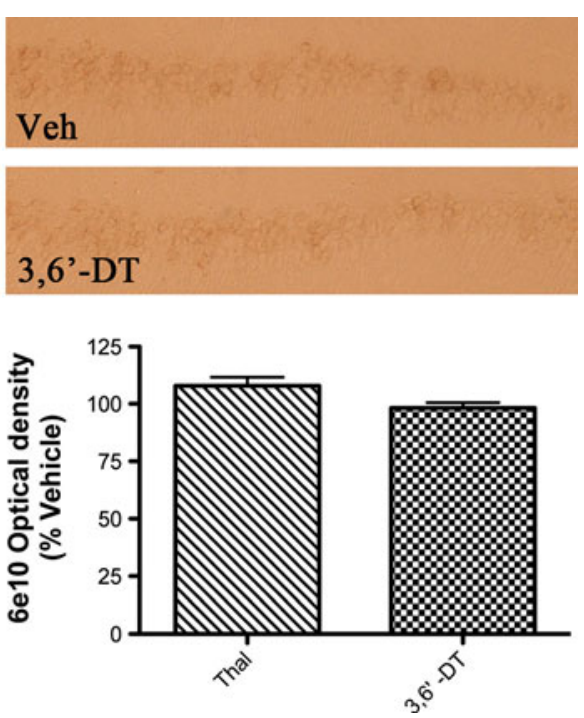

Figure 8 Amyloid precursor protein/amyloid beta peptide staining is not changed in $3 \times \mathbf{T g}$ mice by 3,6'-dithiothalidomide or thalidomide treatment. 6 E10 immunohistochemistry was stereologically analyzed in the hippocampal CA1 to CA2 regions (left graph; $n=5$ to 6 mice per treatment). There were no statistically significant differences in 6E10+ cell counts between treatment groups. Representative photomicrographs of each treatment group are shown. The same regions were also analyzed for optical density (right graph) and show that there were no differences between treatment groups.

reduced prior to beta-amyloid deposition, suggesting that the CD40-CD40L interaction is an early event in $\mathrm{AD}$ pathogenesis [43]. However, complete abrogation of

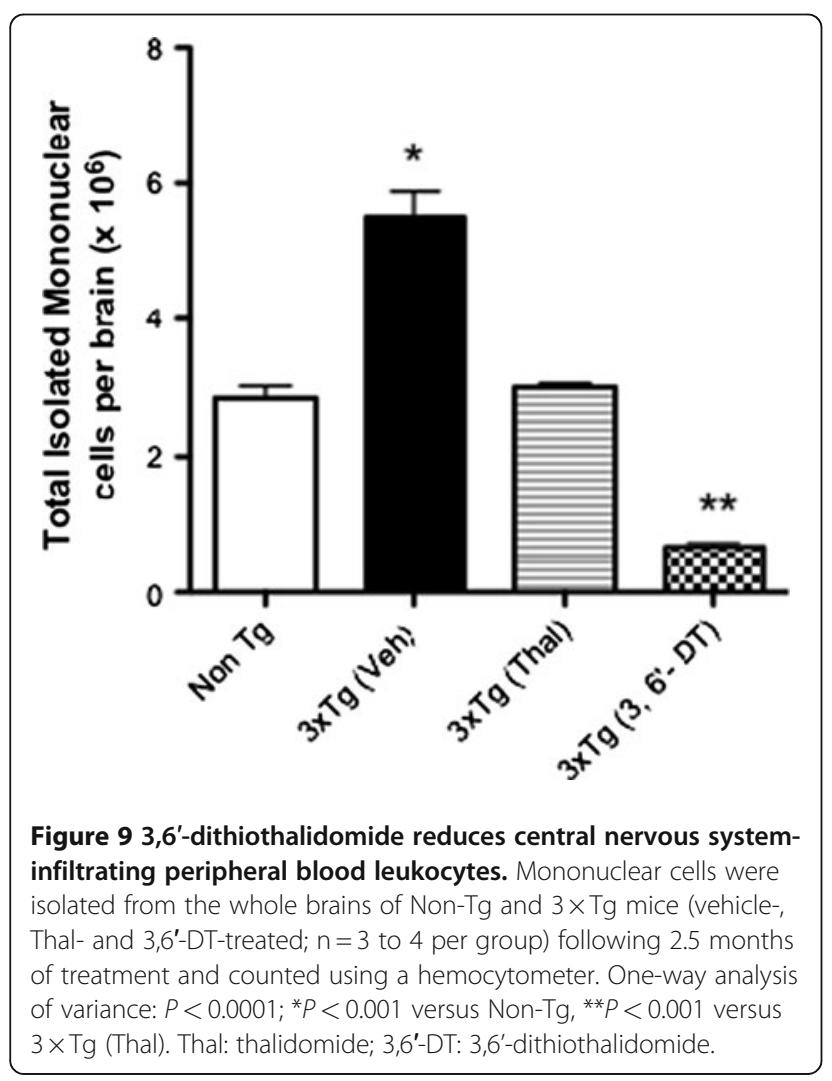

TNF $\alpha$ is not beneficial in the context of AD. Giuliani and coworkers used the PDAPP mouse model to demonstrate increased amyloid plaque burden and no cognitive improvement following chronic TNF $\alpha$ ablation [44]. The dual mission of TNF $\alpha$ may depend on the timing and progression of damage. In a model of traumatic brain injury, TNF $\alpha$-null mice exhibited less severe cognitive and motor neuron impairments than wild type (WT) mice in the acute post-traumatic period [45]. While neurological functions recovered by 2 to 3 weeks post-injury in WT mice, TNF $\alpha$-null animals still demonstrated motor deficits at 4 weeks and brain damage was significantly more extensive in TNF $\alpha$-deficient mice. What remains unclear after these important studies is which approach to pursue in balancing the dual roles of the inflammatory response in $\mathrm{AD}$. Our data indicate that long-term modulation with the small molecule TNF $\alpha$ inhibitor 3,6'-DT is safe, reduces CNS TNF $\alpha$ levels and improves cognitive function in the early stages of disease in the $3 \times \mathrm{Tg}$ mouse. It will be important to assess long-term dosing strategies that encompass later disease stages for safety and impact on the development of the classical neuropathological features of $\mathrm{AD}$, such as tau pathology (not seen at the age of the mice in this study; see $[33,37])$ and amyloid accumulation. It is important to note that, at this early phase of the disease, treatment of $3 \times \mathrm{Tg}$ mice with either Thal or 3,6'-DT did not increase intraneuronal $A \beta$ or $A \beta$ plaque deposition.

TNF $\alpha$ has already been validated as a drug target with infliximab (Remicade), etanercept (Enbrel) and 


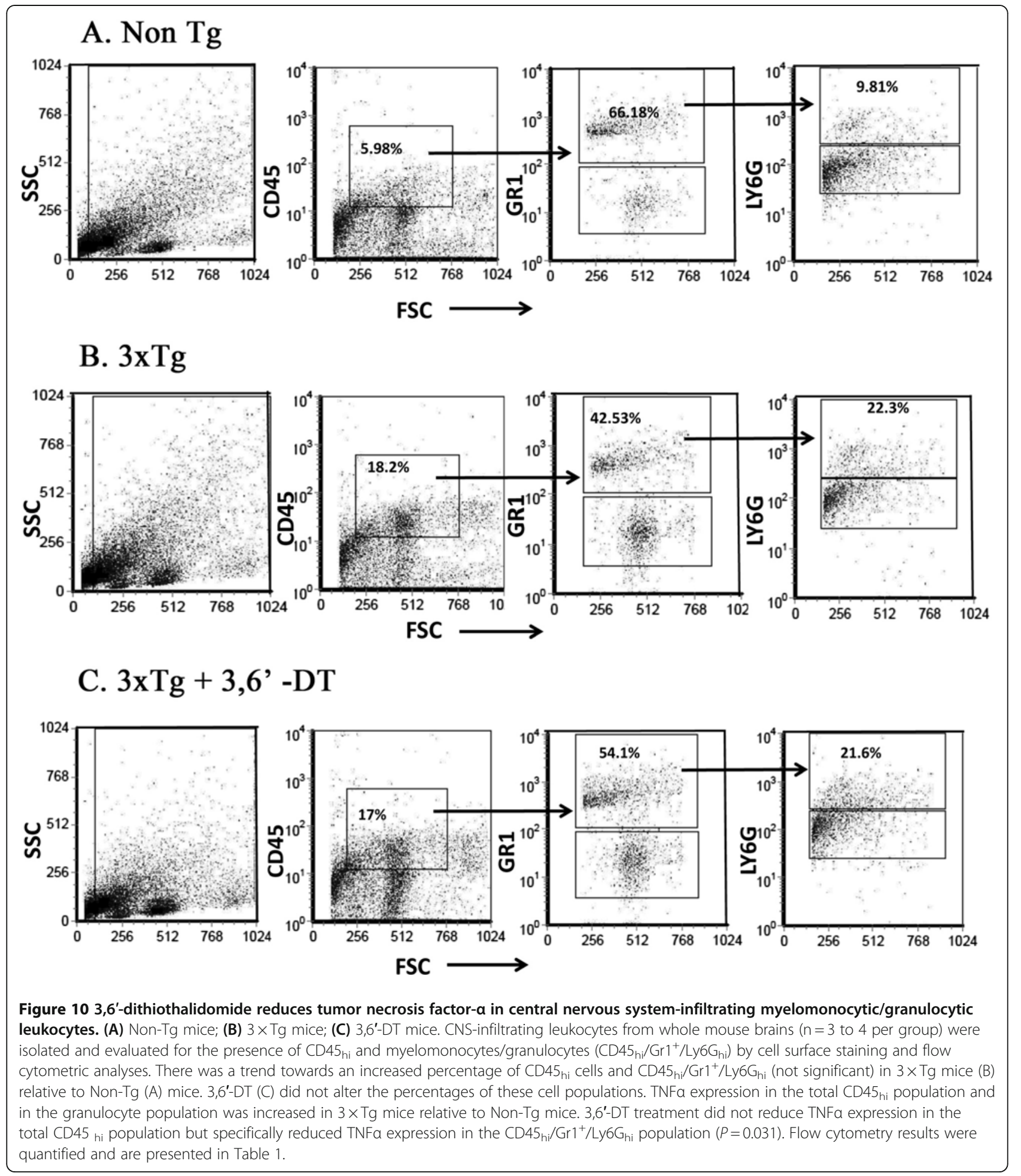

adalimumab (Humira) in clinical use. Short-term, extrathecal etanercept administration in patients with AD achieved significant cognitive and behavioral improvements [46-48]. As AD treatment necessitates chronic, long-term treatment, perispinal injections are neither practical nor safe in this context and the development of small, drug-like molecules to potently and safely inhibit TNF $\alpha$ is of significant clinical value. Thalidomide, a small molecule glutamic acid derivative demonstrating anti-TNF $\alpha$ actions, enhances the degradation of TNF $\alpha$ mRNA [49-51]. Recent preclinical studies indicate the therapeutic potential of employing thalidomide as an AD 
Table 1 Central nervous system-infiltrating peripheral blood-derived leukocytes

\begin{tabular}{lcccc}
\hline & \% CD45 & $\begin{array}{l}\text { \%CD45 } \\
\text { Gr1+/Ly6G } /\end{array}$ & \multicolumn{2}{c}{ Intracellular TNFa } \\
\cline { 4 - 5 } & & & CD45 $_{\text {hi }}$ & CD45 $_{\text {hi }} /$ Gr1+/Ly6G $_{\text {hi }}$ \\
\hline Non-Tg & $6.7 \pm 1.8$ & $5.5 \pm 2.0$ & - & - \\
$\mathbf{3} \times \mathbf{T g}$ & $14.3 \pm 4.9$ & $13.9 \pm 4.4$ & $493 \pm 197.7$ & $88.5 \pm 16.7$ \\
$\mathbf{3} \times \mathbf{T g}$ & $17.4 \pm 1.9$ & $13.6 \pm 1.3$ & $759 \pm 75.3$ & $28.3 \pm 5.2$ \\
$\mathbf{( 3 , 6 ' - D T )}$ & & & & \\
$\mathbf{P}$ & n.s. & n.s. & n.s. & 0.0309 \\
\hline
\end{tabular}

${ }^{\mathrm{a}} \mathrm{TNFa}$ is expressed as a percentage increase from Non-Tg values. $P$-value is $3 \times \operatorname{Tg}$ versus $3 \times \operatorname{Tg}\left(3,6^{\prime}\right.$-dithiothalidomide). Results are expressed as the mean \pm standard error; $n=3$ to 4 mice per group. $n$.s.: not significant; TNFa: tumor necrosis factor-a.

treatment. Daily treatment with thalidomide $(20 \mathrm{mg} / \mathrm{kg})$ improved recognition memory induced by $A(25-35)$ or $A \beta(1-40)$ in mice [52]. These data suggest the practicability of small molecules that target TNF $\alpha$ as a therapeutic strategy against $A \beta$-mediated cognitive impairments. However, thalidomide's use in humans is severely restricted by its well-documented side effects, such as somnolence, deep-vein thrombosis and peripheral neurotoxicity [53]. Thalidomide also has a high $\mathrm{IC}_{50}$ for TNFa inhibition, necessitating chronic high dosing to achieve significant clinical benefit while increasing risk for side effects in patients with AD.

In this report, a novel experimental TNF $\alpha$ synthesis inhibitor, 3,6'-DT [54,55], a lipophilic analog of the classic orally active thalidomide, was evaluated. 3,6'-DT was shown to be effective in ameliorating the TNFo increase and cognitive impairment resulting from a mild traumatic brain injury in mice [36]. In the current study, 3,6'-DT and thalidomide were equally effective, at a high dose, in preventing CNS TNFa increases resulting from LPSinduced systemic inflammation in WT mice. However, only 3,6'-DT was effective at lowering TNF $\alpha$ in the CNS of $3 \times \mathrm{Tg}$ mice and improving cognitive function. The lack of efficacy by thalidomide in the $3 \times \mathrm{Tg}$ model may be due to a higher $\mathrm{IC}_{50}$ value than $3,6^{\prime}$-DT or a difference in brain penetrance. $3,6^{\prime}$-DT has an assessed brain to plasma ratio of 1.34 [36], which is in accord with its partition coefficient (cLogD) value of $-0.56[54,55]$, a measure of its balanced aqueous solubility and lipophilicity. Thalidomide has a moderate degree of lipophilicity with a $\operatorname{cLog} D$ value of -0.83 [56]. Further, thalidomide has demonstrated poor ability in vitro to reduce LPS-stimulated TNF $\alpha$ while significantly increasing toxic nitrite levels [36].

Within the CNS, the main executors of innate immunity are perivascular macrophages and parenchymal microglia [57]. Resting microglia are highly ramified with branched processes and have critical physiologic roles, including determination of neuronal fate, migration, axonal growth and synaptic remodeling $[58,59]$. In response to pathological conditions, microglia transform into a reactive state
$[58,60,61]$, losing their ramified morphology and switching from a neurotrophic phenotype to a persistent, reactive phenotype expressing toxic and reparative functions [59]. Inflammation clearly occurs in pathologically vulnerable regions of the $\mathrm{AD}$ brain $[62,63]$, and both animal models and clinical studies strongly suggest that inflammation significantly contributes to $\mathrm{AD}$ pathogenesis [39]. $3 \times \mathrm{Tg}$ mice showed a large increase in Iba-1 positive microglia at 6.5 months of age compared with Non-Tg mice and the majority of these microglia had an activated morphology. Although both thalidomide and 3,6'-DT reduced the total numbers of Iba-1 positive microglia, only 3,6'-DT improved the ratio of resting to activated microglia and created a microglial morphological profile that was nearly identical to that of the Non-Tg brain. $3 \times \mathrm{Tg}$ mice treated with thalidomide had predominately activated Iba- 1 positive microglia.

Although considerable focus has been given to the CNSendogenous innate immune system, the CNS-endogenous and peripheral immune systems do not function in isolation from each other and there is dynamic interplay. In the healthy brain, peripheral immune cells are indispensable for homeostasis whereas specific cell types play different roles in neuroprotection and neurodestruction [64]. This activity must be tightly regulated or the immune system will become hyperactivated, leading to dysregulation and pathological sequelae. One of the many known functions of TNFo is to stimulate the recruitment of innate effectors such as neutrophils/granulocytes and monocytes and to activate these cells in a paracrine manner. After being activated by injury or disease, innate immune system functions focus on the clearance of pathogens and debris, tissue repair and in orchestrating adaptive immune responses $[58,65,66]$.

While the inflammation within the AD brain has been assumed to be a locally-mediated inflammatory response by microglia to $A \beta$ [39], systemic immune responses may also play a role. Prior to entering the CNS, leukocytes encounter formidable barriers to access including the endothelial blood-brain barrier, the epithelial blood-CSF barrier and the tanycyte barrier surrounding the circumventricular organs [67]. The mechanisms by which leukocytes infiltrate the healthy brain during adulthood and aging are not clear [68], but there is strong evidence that a compromised blood-brain barrier in brain diseases, such as stroke or brain trauma [69], and AD [70-75] allows leakage of leukocytes into the brain. TNF $\alpha$ can cause vascular endothelial damage and an increase in vascular endothelial permeability [76]. In regards to macrophage infiltration into the CNS, there are no specific immunohistochemical markers to distinguish bloodderived macrophages from brain endogenous microglial cells, making the distinction difficult. Recent human studies demonstrate that recruited monocytic cells 
express markers for microglia yet are morphologically and functionally separate from the resident microglia in the AD brain [71-75]. Contradicting the importance of leukocytes in $\mathrm{AD}$ pathology, histological examination of postmortem $\mathrm{AD}$ brains has not demonstrated abundant leukocytic infiltrates. Future studies and more sophisticated methodologies are required to determine if this is a disease stage phenomenon and what contributions infiltrating leukocytes may make to early stage $\mathrm{AD}$ and progression of the disease. In this regard, animal models of $\mathrm{AD}$ are valuable.

Recent studies in AD animal model pathology have elegantly examined the important role that brain-infiltrating monocytes play in A $\beta$ clearance. Angelucci et al. crossed an AD mouse model with an animal deficient in CC-chemokine receptor 2 [77]. These bigenic mice have markedly diminished recruitment of brain resident microglia and/or peripheral macrophages to sites of beta-amyloid plaques and demonstrate heavier $A \beta$ protein burden than $A D$ model mice alone. While this study does not definitively establish the provenance of the amyloid clearing cells, it demonstrates the importance of brain innate immunity in restricting cerebral amyloidosis. An additional report has shown that depletion of CD11c + cells using a CD11c-diphtheria toxin transgenic mouse bone marrow chimera in an AD mouse model opposes the beneficial effect of $\mathrm{T}$ celldirected immunotherapy, suggesting that peripheral innate immune cells are required for $A \beta$ clearance [78]. These studies, by negatively impacting brain penetration and $A \beta$ homing of these peripheral innate immune cells, lead to the deduction that such cells are critical for reducing amyloid accumulation. However, if these cells are to be targeted as a therapeutic modality, strategies for selectively increasing brain leukocyte infiltration and increasing $A \beta$ clearance potential need to be developed. A recent study demonstrated that blood-borne monocytes can be encouraged to enter the brain and restrict $A \beta$ plaques without producing a potentially damaging neuroinflammatory response [79].

Previous work [80] and the current study demonstrate that the $3 \times \mathrm{Tg}$ mouse has a robust increase in CNS leukocyte infiltrates early in the disease process, and that intracellular TNF $\alpha$ levels in this population are greatly increased relative to Non-Tg mice. Both thalidomide and $3,6^{\prime}$-DT reduced the total numbers of infiltrating peripheral leukocytes in the CNS of $3 \times \mathrm{Tg}$ mice as measured by flow cytometry but 3,6'-DT effected a striking reduction. The similar parallel finding of reduced Iba-1 microglia following thalidomide or 3,6'-DT treatment suggest that reducing the infiltrating leukocyte population contributed to the reduction in Iba-1 positive microglia. Additionally, only 3,6'-DT improved the resting to activated ratio of CNS microglia suggesting that the improved CNS penetrance and lower $\mathrm{IC}_{50}$ of 3,6'-DT compared with thalidomide is necessary for efficacy.
3,6'-DT did not, however, change the percentages of specific cell types within the total leukocytic population or alter TNF $\alpha$ levels in the total $\mathrm{CD} 45_{\mathrm{hi}}$ population. Rather, 3,6'-DT specifically reduced intracellular TNF $\alpha$ levels in the $\mathrm{CD} 45_{\mathrm{hi}} / \mathrm{GR} 1^{+} / \mathrm{Ly} 6 \mathrm{G}_{\mathrm{hi}}$ (granulocytic) subpopulation. Due to a paucity of studies, it is unclear what the role of granulocytes is in the human AD brain, particularly in the early stages of the disease, and further studies are needed to determine if granulocytes migrate through the brain parenchyma or are involved in inflammatory signal transduction from the perivascular regions of the brain. Regardless, these data raise interesting questions about $\mathrm{AD}$ immunotherapy and suggests that, in addition to reducing the total number of infiltrating leukocytes, modulation of TNF $\alpha$ by small molecule TNF $\alpha$ inhibitors, in specific subsets of peripheral leukocytes, may be therapeutic.

Chronic neuroinflammation is an important component of AD pathogenesis and undoubtedly contributes to neuronal dysfunction, injury, loss and disease progression. A recent proteomic profiling study examined the CSF of young individuals who will go on to develop familial AD in comparison with age-matched controls not carrying a familial AD mutation [81]. The study noted increases in multiple complement cascade components as much as a decade prior to the onset of overt AD symptomology, indicating that neuroinflammation plays a very early role in the disease process. These and other data underscore the therapeutic potential of targeted anti-inflammatory pharmaceuticals both early and throughout the course of the disease. Unfortunately, our knowledge of CNS-related immune function is currently limited and the study of the interface between the peripheral and CNS-endogenous immune systems is in its infancy. Understanding the molecular manipulations required to produce beneficial changes in leukocyte and microglial activation profiles is necessary to beget more sophisticated immunomodulatory strategies for the treatment of AD.

\section{Abbreviations \\ 3,6'-DT: 3,6'-dithiothalidomide; $3 \times$ TgAD: Triple transgenic Alzheimer's disease mice harboring PS1 ${ }_{M 146 V}, A P_{\text {Swe }}$ and taup301L; $A \beta$ : Amyloid beta peptide; AD: Alzheimer's disease; ANOVA: analysis of variance; APC: Allophycocyanin; APP: Amyloid precursor protein; CLog D: Partition coefficient; CM: Culture medium; CNS: Central nervous system; CSF: Cerebrospinal fluid; DMEM: Dulbecco's modified Eagle medium; DMSO: Dimethyl sulfoxide; ELISA: Enzyme-linked immunosorbent assay; FACS: Fluorescence activated cell sorting; FBS: Fetal bovine serum; Iba-1: Ionized calcium-binding adapter molecule $1 ; I_{50}$ : Half maximal inhibitory concentration; IL: Interleukin; i. p: Intraperitoneal injection; LDH: Lactate dehydrogenase; \\ LPS: Lipopolysaccharide; MCl: Mild cognitive impairment; Non-Tg: Non- transgenic; PBS: Phosphate-buffered saline; PCR: Polymerase chain reaction; PerCP: Peridinin-chlorophyll-protein-complex; PS1: Presenilin 1; RAM: Radial arm maze; Thal: Thalidomide; TNFa: Tumor necrosis factor-alpha; WT: Wild type.}

\section{Competing interests}

SPG and FPZ are employees of P2D, Inc. and declare a financial competing interest. All other authors declare no competing interests. 


\section{Acknowledgments}

The authors would like to thank Dr. Russell Brown at Eastern Tennessee State University for assistance with the design and analysis of the Radial Arm Maze experiments, Dr. Louis Hersh at the University of Kentucky for providing breeding pairs of $3 \times \mathrm{Tg}$ mice and Dr. Kenneth Hensley at the University of Toledo for assistance with data interpretation and critical scientific review of the manuscript. This work was supported by Veterans Administration Merit Funding (MEHW and SPS), Michael J. Fox Foundation (SPG), Alzheimer's Drug Discovery Foundation (MEHW and SPG) and the Intramural Research Program of NIA, NIH (DT and NHG).

\section{Author details}

${ }^{1}$ P2D Bioscience, Cincinnati, OH 45242, USA. ${ }^{2}$ Veterans Administration-Greater Los Angeles Healthcare System and Department of Medicine, David Geffen School of Medicine at UCLA, 11301 Wilshire Boulevard, (151), Los Angeles, CA 90073, USA. ${ }^{3}$ National Institute on Aging, National Institutes of Health Laboratory of Neurosciences, Intramural Research Program, Baltimore, MD 21224, USA.

\section{Authors' contributions}

MEH-W participated in the design of the study, performed design-based stereology, isolated brain mononuclear cells, performed data and statistical analyses and drafted the manuscript. SPG participated in the design of the study, drug synthesis, data analysis and participated in drafting the manuscript. MKS and SPS conducted the flow cytometry work and subsequent data analysis. PE conducted all tissue extractions and ELISA and RT-PCR work. MFJ performed all immunohistochemical procedures, RAM studies and assisted with stereology. NK performed all cell culture and in vitro ELISA procedures. FPZ participated in the design of the study and in revising the manuscript. NHG is the primary inventor of the US patent covering 3,6'-DT (US patent 7,973,057 B2). DT and NHG made contributions to the concept of 3,6'-DT use in these studies, performed the chemical characterization and quality control of 3,6'-DT for cell culture studies, provided preliminary data on cellular and in vivo activity for appropriate dosing and participated in drafting the manuscript. All authors read and approved the final manuscript.

Received: 24 January 2012 Accepted: 25 May 2012 Published: 25 May 2012

\section{References}

1. Carswell EA, Old L, Kassel RL, Green S, Fiore N, Williamson B: An endotoxin- induced serum factor that causes necrosis of tumors. Proc Natl Acad Sci USA 1975, 72:3666-3670.

2. Sedel F, Bechade C, Vyas S, Triller A: Macrophage-derived tumor necrosis factor alpha, an early developmental signal for motoneuron death. J Neurosci 2004, 24:2236-2246.

3. Bernardino L, Agasse F, Silva B, Ferreira R, Grade S, Malva JO: Tumor necrosis factor-alpha modulates survival, proliferation, and neuronal differentiation in neonatal subventricular zone cell cultures. Stem Cell 2008, 26:2361-2371.

4. Keohane A, Ryan S, Maloney E, Sullivan AM, Nolan YM: Tumour necrosis factor- alpha impairs neuronal differentiation but not proliferation of hippocampal neural precursor cells: role of Hes1. Mol Cell Neurosci 2010, 43:127-135.

5. Obregon E, Punzon C, Fernandez-Cruz E, Fresno M, Munoz-Fernandez MA: HIV-1 infection induces differentiation of immature neural cells through autocrine tumor necrosis factor and nitric oxide production. Virology 1999, 261:193-204.

6. Neumann H, Schweigreiter R, Yamashita T, Rosenkranz K, Wekerle H, Barde YA: Tumor necrosis factor inhibits neurite outgrowth and branching of hippocampal neurons by a rho-dependent mechanism. J Neurosci 2002, 22:854-862.

7. Beattie EC, Stellwagen D, Morishita W, Bresnahan JC, Ha BK, von Zastrow M, Beattie MS, Malenka RC: Control of synaptic strength by glial TNFalpha. Science 2002, 295:2282-2285.

8. Fujii S, Matsumoto M, Igarashi K, Kato H, Mikoshiba K: Synaptic plasticity in hippocampal CA1 neurons of mice lacking type 1 inositol-1,4, 5-trisphosphate receptors. Learn Mem 2000, 7:312-320.
9. Park KM, Yule DI, Bowers WJ: Tumor necrosis factor-alpha potentiates intraneuronal $\mathrm{Ca} 2+$ signaling via regulation of the inositol 1,4, 5-trisphosphate receptor. J Biol Chem 2008, 283:33069-33079.

10. Steinmetz CC, Turrigiano GG: Tumor necrosis factor-alpha signaling maintains the ability of cortical synapses to express synaptic scaling. J Neurosci 2010, 30:14685-14690.

11. Wheeler D, Knapp E, Bandaru W, Wang Y, Knorr D, Poirier C, Mattson MP, Geiger JD, Haughey NJ: Tumor necrosis factor-alpha-induced neutral sphingomyelinase-2 modulates synaptic plasticity by controlling the membrane insertion of NMDA receptors. J Neurochem 2009, 109:1237-1249.

12. Montgomery SL, Bowers WJ: Tumor necrosis factor-alpha and the roles it plays in homeostatic and degenerative processes within the central nervous system. J Neuroimmune Pharmacol 2012, 7:42-59.

13. McGeer EG, McGeer PL: Inflammatory processes in Alzheimer's disease. Prog Neuropsychopharmacol Biol Psychiatr 2003, 27:741-749.

14. Standridge JB: Pharmacotherapeutic approaches to the prevention of Alzheimer's disease. Am J Geriatr Pharmacother 2004, 2:119-132.

15. Craft JM, Watterson DM, van Eldik L: Neuroinflammation: a potential therapeutic target. Expert Opin Ther Targets 2005, 9:887-900.

16. Hu W, Ralay Ranaivo H, Craft JM, van Eldik L, Watterson DM: Validation of the neuroinflammation cycle as a drug discovery target using integrative chemical biology and lead compound development with an Alzheimer's disease -related mouse model. Curr Alzheimer Res 2005, 2:197-205.

17. Jacobsen JS, Reinhart P, Pangalos MN: Current concepts in therapeutic strategies targeting cognitive decline and disease modification in Alzheimer's disease. NeuroRx 2005, 2:612-626.

18. Kelleher-Andersson J: Discovery of neurogenic, Alzheimer's disease therapeutics. Curr Alzheimer Res 2006, 3:55-62.

19. Ralay Ranaivo H, Craft JM, Hu W, Guo L, Wing LK, Van Eldik L, Watterson DM: Glia as a therapeutic target: selective suppression of human amyloid -beta-induced upregulation of brain proinflammatory cytokine production attenuates neurodegeneration. J Neurosci 2006, 26:662-670.

20. Rosenberg PB: Clinical aspects of inflammation in Alzheimer's disease. Int Rev Psychiatr 2005, 17:503-514.

21. Combs CK, Karlo JC, Kao SC, Landreth GE: beta-Amyloid stimulation of microglia and monocytes results in TNFalpha-dependent expression of inducible nitric oxide synthase and neuronal apoptosis. J Neurosci 2001, 21:1179-1188.

22. Griffin WS, Sheng JG, Royston MC, Gentleman SM, McKenzie JE, Graham DI, Roberts GW, Mrak RE: Glial-neuronal interactions in Alzheimer's disease: the potential role of a 'cytokine cycle' in disease progression. Brain Pathol 1998, 8:65-72.

23. Zhao M, Cribbs DH, Anderson AJ, Cummings BJ, Su JH, Wasserman AJ, Cotman CW: The induction of the TNFalpha death domain signaling pathway in Alzheimer's disease brain. Neurochem Res 2003, 28:307-318.

24. Alvarez S, Blanco A, Fresno M, Munoz-Fernandez MA: TNF-alpha contributes to caspase-3 independent apoptosis in neuroblastoma cells: role of NFAT. PLoS One 2011, 6:e16100.

25. Tarkowski E, Blennow K, Wallin A, Tarkowski A: Intracerebral production of tumor necrosis factor-alpha, a local neuroprotective agent, in Alzheimer disease and vascular dementia. J Clin Immunol 1999, 19:223-230.

26. Tarkowski E, Andreasen N, Tarkowski A, Blennow K: Intrathecal inflammation precedes development of Alzheimer's disease. J Neurol Neurosurg Psychiatry 2003, 74:1200-1205.

27. Alvarez A, Cacabelos R, Sanpedro C, Garcia-Fantini M, Aleixandre M: Serum TNF- alpha levels are increased and correlate negatively with free IGF-I in Alzheimer disease. Neurobiol Aging 2007, 28:533-536.

28. Medeiros R, Prediger RD, Passos GF, Pandolfo P, Duarte FS, Franco JL, Dafre AL, Di Giunta G, Figueiredo CP, Takahashi RN, et al: Connecting TNF-alpha signaling pathways to iNOS expression in a mouse model of Alzheimer's disease: relevance for the behavioral and synaptic deficits induced by amyloid beta protein. J Neurosci 2007, 27:5394-5404.

29. Mehlhorn G, Hollborn M, Schliebs R: Induction of cytokines in glial cells surrounding cortical beta-amyloid plaques in transgenic Tg2576 mice with Alzheimer pathology. Int J Dev Neurosci 2000, 18:423-431.

30. Ruan L, Kang Z, Pei G, Le Y: Amyloid deposition and inflammation in APPswe/ PS1dE9 mouse model of Alzheimer's disease. Curr Alzheimer Res 2009, 6:531-540.

31. Janelsins MC, Mastrangelo MA, Oddo S, LaFerla FM, Federoff HJ, Bowers WJ: Early correlation of microglial activation with enhanced tumor necrosis factor-alpha and monocyte chemoattractant protein-1 expression specifically within the entorhinal cortex of triple transgenic Alzheimer's disease mice. I Neuroinflammation 2005, 2:23. 
32. Billings LM, Oddo S, Green KN, McGaugh JL, LaFerla FM: Intraneuronal Abeta causes the onset of early Alzheimer's disease-related cognitive deficits in transgenic mice. Neuron 2005, 45:675-688.

33. Oddo S, Caccamo A, Kitazawa M, Tseng BP, LaFerla FM: Amyloid deposition precedes tangle formation in a triple transgenic model of Alzheimer's disease. Neurobiol Aging 2003, 24:1063-1070.

34. Franklin KBJ, Paxinos G: The mouse brain in stereotaxic coordinates. 3rd edition. San Diego, CA: Academic; 2007.

35. Pino PA, Cardona AE: Isolation of brain and spinal cord mononuclear cells using percoll gradients. J Vis Exp 2011, 48:e2348.

36. Baratz R, Tweedie D, Rubovitch V, Luo W, Yoon JS, Hoffer BJ, Greig NH, Pick CG: Tumor necrosis factor-alpha synthesis inhibitor, 3,6'dithiothalidomide, reverses behavioral impairments induced by minimal traumatic brain injury in mice. J Neurochem 2011, 118:1032-1042.

37. Oddo S, Caccamo A, Shepherd JD, Murphy MP, Golde TE, Kayed R, Metherate R, Mattson MP, Akbari Y, LaFerla FM: Triple-transgenic model of Alzheimer's disease with plaques and tangles: intracellular Abeta and synaptic dysfunction. Neuron 2003, 39:409-421.

38. Rothwell NJ, Relton JK: Involvement of interleukin-1 and lipocortin-1 in ischaemic brain damage. Cerebrovasc Brain Metab Rev 1993, 5:178-198.

39. Akiyama H, Barger S, Barnum S, Bradt B, Bauer J, Cole GM, Cooper NR, Eikelenboom P, Emmerling M, Fiebich BL, Finch CE, Frautschy S, Griffin WS, Hampel H, Hull M, Landreth G, Lue L, Mrak R, Mackenzie IR, McGeer PL, O'Banion MK, Pachter J, Pasinetti G, Plata-Salaman C, Rogers J, Rydel R, Shen Y, Streit W, Strohmeyer R, Tooyoma I, et al: Inflammation and Alzheimer's disease. Neurobiol Aging 2000, 21:383-421.

40. Arnett HA, Mason J, Marino M, Suzuki K, Matsushima GK, Ting JP: TNF alpha promotes proliferation of oligodendrocyte progenitors and remyelination. Nat Neurosci 2001, 4:1116-1122.

41. Shi JQ, Shen W, Chen J, Wang BR, Zhong LL, Zhu YW, Zhu HQ, Zhang QQ, Zhang YD, Xu J: Anti-TNF-alpha reduces amyloid plaques and tau phosphorylation and induces CD11c-positive dendritic-like cell in the APP/PS1 transgenic mouse brains. Brain Res 2011, 1368:239-247.

42. Calingasan NY, Erdely HA, Altar CA: Identification of CD40 ligand in Alzheimer's disease and in animal models of Alzheimer's disease and brain injury. Neurobiol Aging 2002, 23:31-39.

43. Tan J, Town T, Paris D, Mori T, Suo Z, Crawford F, Mattson MP, Flavell RA, Mullan M: Microglial activation resulting from CD40-CD40L interaction after beta-amyloid stimulation. Science 1999, 286:2352-2355.

44. Giuliani F, Vernay A, Leuba G, Schenk F: Decreased behavioral impairments in an Alzheimer mice model by interfering with TNF-alpha metabolism. Brain Res Bull 2009, 80:302-308.

45. Scherbel U, Raghupathi R, Nakamura M, Saatman KE, Trojanowski JQ Neugebauer E, Marino MW, Mclntosh TK: Differential acute and chronic responses of tumor necrosis factor-deficient mice to experimental brain injury. Proc Natl Acad Sci U S A 1999, 96:8721-8726.

46. Tobinick E, Gross H, Weinberger A, Cohen H: TNF-alpha modulation for treatment of Alzheimer's disease: a 6-month pilot study. MedGenMed 2006, 8:25

47. Tobinick EL, Gross H: Rapid improvement in verbal fluency and aphasia following perispinal etanercept in Alzheimer's disease. BMC Neurol 2008, 8:27.

48. Tobinick EL, Gross H: Rapid cognitive improvement in Alzheimer's disease following perispinal etanercept administration. J Neuroinflammation 2008, 5:2.

49. Kruys V, Marinx O, Shaw G, Deschamps J, Huez G: Translational blockade imposed by cytokine-derived UA-rich sequences. Science 1989, 245:852-855

50. Moreira AL, Sampaio EP, Zmuidzinas A, Frindt P, Smith KA, Kaplan G: Thalidomide exerts its inhibitory action on tumor necrosis factor alpha by enhancing mRNA degradation. J Exp Med 1993, 177:1675-1680

51. Sampaio EP, Sarno EN, Galilly R, Cohn ZA, Kaplan G: Thalidomide selectively inhibits tumor necrosis factor alpha production by stimulated human monocytes. J Exp Med 1991, 173:699-703.

52. Alkam T, Nitta A, Mizoguchi H, Saito K, Seshima M, Itoh A, Yamada K, Nabeshima T: Restraining tumor necrosis factor-alpha by thalidomide prevents the amyloid beta-induced impairment of recognition memory in mice. Behav Brain Res 2008, 189:100-106.

53. Tariman JD: Thalidomide: current therapeutic uses and management of its toxicities. Clin J Oncol Nurs 2003, 7:143-147.

54. Zhu X, Giordano T, Yu QS, Holloway HW, Perry TA, Lahiri DK, Brossi A, Greig $\mathrm{NH}$ : Thiothalidomides: novel isosteric analogues of thalidomide with enhanced TNF-alpha inhibitory activity. J Med Chem 2003, 46:5222-5229.
55. Greig NH, Giordano T, Zhu X, Yu QS, Perry TA, Holloway HW, Brossi A, Rogers JT, Sambamurti K, Lahiri DK: Thalidomide-based TNF-alpha inhibitors for neurodegenerative diseases. Acta Neurobiol Exp (Wars) 2004, 64:1-9.

56. Luo W, Yu QS, Salcedo I, Holloway HW, Lahiri DK, Brossi A, Tweedie D, Greig $\mathrm{NH}$ : Design, synthesis and biological assessment of novel $\mathrm{N}$-substituted 3-(phthalimidin-2-yl)-2,6-dioxopiperidines and 3-substituted 2,6dioxopiperidines for TNF-alpha inhibitory activity. Bioorg Med Chem 2011, 19:3965-3972

57. Kadiu I, Glanzer JG, Kipnis J, Gendelman HE, Thomas MP: Mononuclear phagocytes in the pathogenesis of neurodegenerative diseases. Neurotox Res 2005, 8:25-50.

58. Hanisch UK, Kettenmann H: Microglia: active sensor and versatile effector cells in the normal and pathologic brain. Nat Neurosci 2007, 10:1387-1394.

59. Streit WJ: Microglial senescence: does the brain's immune system have an expiration date? Trends Neurosci 2006, 29:506-510.

60. Glanzer JG, Enose Y, Wang T, Kadiu I, Gong N, Rozek W, Liu J, Schlautman JD, Ciborowski PS, Thomas MP, Gendelman HE: Genomic and proteomic microglial profiling: pathways for neuroprotective inflammatory responses following nerve fragment clearance and activation. $J$ Neurochem 2007, 102:627-645.

61. Smith JA, Das A, Ray SK, Banik NL: Role of pro-inflammatory cytokines released from microglia in neurodegenerative diseases. Brain Res Bull 2012, 87:10-20.

62. Streit WJ: Microglia and Alzheimer's disease pathogenesis. J Neurosci Res 2004, 77:1-8.

63. Streit WJ, Mrak RE, Griffin WS: Microglia and neuroinflammation: a pathological perspective. J Neuroinflammation 2004, 1:14.

64. Chen ML, Yan BS, Bando Y, Kuchroo VK, Weiner HL: Latency-associated peptide identifies a novel CD4 + CD25+ regulatory $T$ cell subset with TGFbeta -mediated function and enhanced suppression of experimental autoimmune encephalomyelitis. J Immunol 2008, 180:7327-7337.

65. Mosser DM, Edwards JP: Exploring the full spectrum of macrophage activation. Nat Rev Immunol 2008, 8:958-969.

66. Pichlmair A, RE Sousa C: Innate recognition of viruses. Immunity 2007 27:370-383.

67. Engelhardt B: The blood-central nervous system barriers actively control immune cell entry into the central nervous system. Curr Pharm Des 2008 14:1555-1565

68. Mildner A, Schmidt H, Nitsche M, Merkler D, Hanisch UK, Mack M, Heikenwalder M, Bruck W, Priller J, Prinz M: Microglia in the adult brain arise from Ly -6ChiCCR2+ monocytes only under defined host conditions. Nat Neurosci 2007, 10:1544-1553.

69. Priller J, Flugel A, Wehner T, Boentert M, Haas CA, Prinz M, Fernandez-Klett F, Prass K, Bechmann I, de Boer BA, Frotscher M, Kreutzberg GW, Persons DA, Dirnagl U: Targeting gene-modified hematopoietic cells to the central nervous system: use of green fluorescent protein uncovers microglial engraftment. Nat Med 2001, 7:1356-1361.

70. Butovsky O, Koronyo-Hamaoui M, Kunis G, Ophir E, Landa G, Cohen H, Schwartz M: Glatiramer acetate fights against Alzheimer's disease by inducing dendritic-like microglia expressing insulin-like growth factor 1. Proc Natl Acad Sci U S A 2006, 103:11784-11789.

71. Fiala M, Liu QN, Sayre J, Pop V, Brahmandam V, Graves MC, Vinters HV: Cyclooxygenase-2-positive macrophages infiltrate the Alzheimer's disease brain and damage the blood-brain barrier. Eur J Clin Invest 2002, 32:360-371.

72. Malm TM, Koistinaho M, Parepalo M, Vatanen T, Ooka A, Karlsson S, Koistinaho J: Bone-marrow-derived cells contribute to the recruitment of microglial cells in response to beta-amyloid deposition in APP/PS1 double transgenic Alzheimer mice. Neurobiol Dis 2005, 18:134-142.

73. Malm TM, Magga J, Kuh GF, Vatanen T, Koistinaho M, Koistinaho J: Minocycline reduces engraftment and activation of bone marrowderived cells but sustains their phagocytic activity in a mouse model of Alzheimer's disease. Glia 2008, 56:1767-1779.

74. Simard AR, Soulet D, Gowing G, Julien JP, Rivest S: Bone marrow-derived microglia play a critical role in restricting senile plaque formation in Alzheimer's disease. Neuron 2006, 49:489-502

75. Stalder AK, Ermini F, Bondolfi L, Krenger W, Burbach GJ, Deller T, Coomaraswamy J, Staufenbiel M, Landmann R, Jucker M: Invasion of hematopoietic cells into the brain of amyloid precursor protein transgenic mice. J Neurosci 2005, 25:11125-11132. 
76. Sharief MK, Thompson EJ: In vivo relationship of tumor necrosis factoralpha to blood-brain barrier damage in patients with active multiple sclerosis. J Neuroimmunol 1992, 38:27-34.

77. Angelucci F, Gruber SH, El Khoury A, Tonali PA, Mathe AA: Chronic amphetamine treatment reduces NGF and BDNF in the rat brain. Eur Neuropsychopharmacol 2007, 17:756-762.

78. Butovsky O, Kunis G, Koronyo-Hamaoui M, Schwartz M: Selective ablation of bone marrow-derived dendritic cells increases amyloid plaques in a mouse Alzheimer's disease model. Eur J Neurosci 2007, 26:413-416.

79. Town T, Laouar Y, Pittenger C, Mori T, Szekely CA, Tan J, Duman RS, Flavell RA: Blocking TGF-beta-Smad2/3 innate immune signaling mitigates Alzheimer-like pathology. Nat Med 2008, 14:681-687.

80. Subramanian S, Ayala P, Wadsworth TL, Harris CJ, Vandenbark AA, Quinn JF Offner H: CCR6: a biomarker for Alzheimer's-like disease in a triple transgenic mouse model. J Alzheimers Dis 2010, 22:619-629.

81. Ringman JM, Schulman H, Becker C, Jones T, Bai Y, Immermann F, Cole G, Sokolow S, Gylys K, Geschwind DH, Cummings IL, Wan HI: Proteomic changes in cerebrospinal fluid of presymptomatic and affected persons carrying familial Alzheimer disease mutations. Arch Neurol 2012, 69:96104.

doi:10.1186/1742-2094-9-99

Cite this article as: Gabbita et al:: Early intervention with a small molecule inhibitor for tumor necrosis factor-a prevents cognitive deficits in a triple transgenic mouse model of Alzheimer's disease. Journal of Neuroinflammation 2012 9:99.

\section{Submit your next manuscript to BioMed Central and take full advantage of:}

- Convenient online submission

- Thorough peer review

- No space constraints or color figure charges

- Immediate publication on acceptance

- Inclusion in PubMed, CAS, Scopus and Google Scholar

- Research which is freely available for redistribution 